\title{
THE IMPACT OF PROTECTIONISM ON THE COMPLETION AND DURATION OF CROSS-BORDER ACQUISITIONS
}

BY

\section{REHANNA CALLAGHAN}

Supervisor: Dr Weiting Zheng

\begin{abstract}
A thesis
submitted to the Victoria University of Wellington

in fulfilment of the requirements for the degree of

Master of Commerce in International Business
\end{abstract}

Victoria University of Wellington

(2018) 


\begin{abstract}
This study investigates the impact of protectionism in a host country on the completion likelihood of an announced cross-border acquisition and the time required to complete the acquisition. Adopting a legitimacy perspective, I identify and test boundary conditions at the firm and national levels to study the relationship between protectionism and crossborder acquisition completion and duration. I hypothesise that in host countries with a high level of protectionism, as reflected by the level of non-tariff barriers, cross-border acquisitions are less likely to be completed and the time taken to close the acquisition deal increases. I also propose that the relationships between protectionism and acquisition outcomes are moderated by critical target firm characteristics and the host country's economic condition. Specifically, these moderators include target firm size, target firm performance, the degree to which the target industry is sensitive to national security concerns, and the host country's GDP growth. I test these hypotheses using a sample of 675 cross-border acquisition attempts by firms in the manufacturing and services industries (excluding financial services) into the U.S. and Canada between 1995 and 2015. The results of the statistical analysis support the prediction that the higher the degree of protectionism, the lower likelihood of acquisition completion and the longer the duration is between acquisition announcement and completion. Findings also support the predicted moderating effects of the target firm size, performance and national security concern. However, the hypothesised moderating effect of the host country's GDP growth was not supported by the results. This finding suggests that host country protectionism impacts cross-border acquisition attempts, irrespective of the host country's economic development. These findings have significant implications for legitimacy-based explanations of cross-border acquisitions. In particular, the results of this study indicate that when protectionism is high, the host country is more likely to raise concerns around the legitimacy of foreign firms. In turn, these firms face adverse host country scrutiny which can result in a failed acquisition attempt, or an extended and therefore, costlier acquisition deal. The framework and findings of this study contribute to an institution-based view and, in particular, to a legitimacy-based perspective in the research on the internationalisation of firms.
\end{abstract}




\section{Acknowledgements}

I am indebted to my supervisor, Dr Weiting Zheng, for her guidance during this project.

This thesis could not have been written and completed without her direction and pragmatism. Her contributions have been an enormous asset. I also want to thank Katrina Walsh for proofreading my thesis. I offer my regards to my close friends and family for lending their encouragement, shoulders, ears, time, and resources to me throughout this process. Finally, I owe my deepest gratitude to my dad Mark and my partner Tarquin. I simply would not have been able to tackle this project, nor the time at university preceding it, without their immense support. 


\section{Table of Contents}

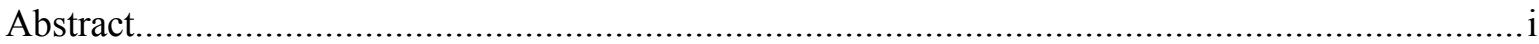

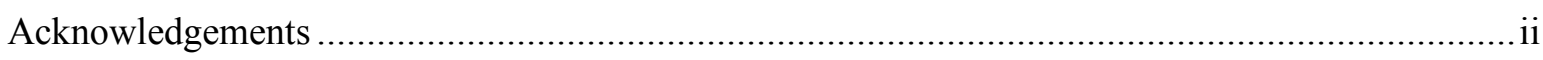

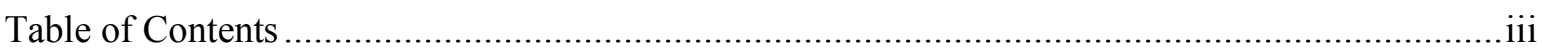

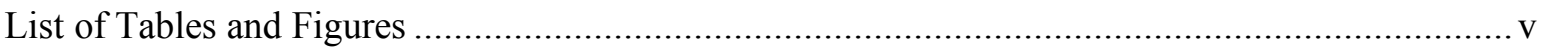

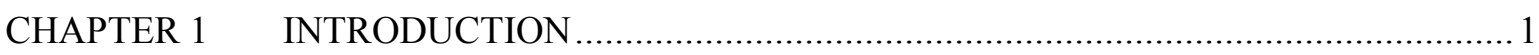

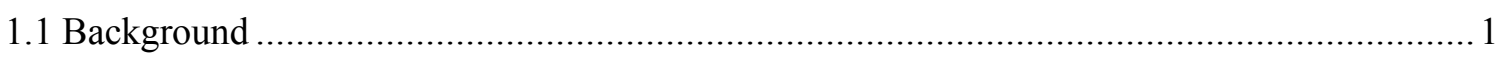

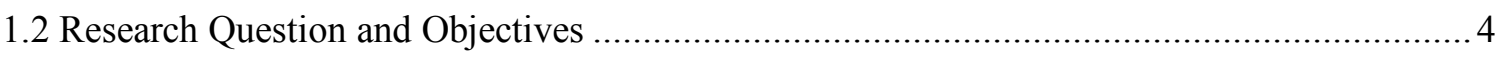

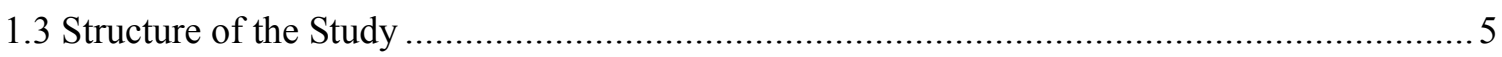

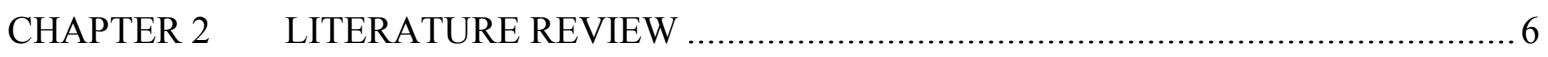

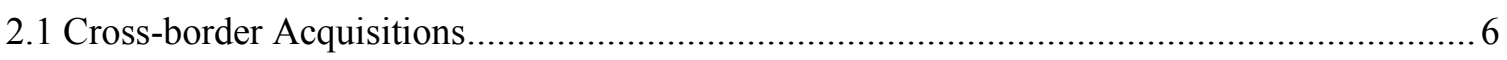

2.2 Cross-border Acquisition Completion and Duration ...................................................... 7

2.3 An Institutional Perspective on Cross-border Acquisition Completion and Duration............. 9

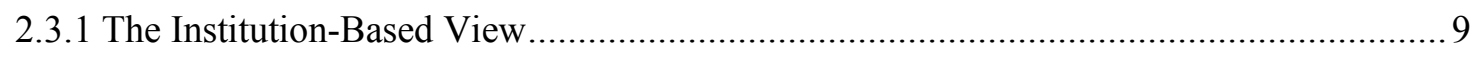

2.3.2 Institutional Differences and Cross-border Acquisition Completion and Duration......... 10

2.3.3 Formal Institutions and Cross-Border Acquisition Completion and Duration ................ 12

2.3.4 Political Institutions and Cross-border Acquisition Completion and Duration ............... 14

2.3.5 Regulatory Institutions and Cross-border Acquisition Completion and Duration........... 15

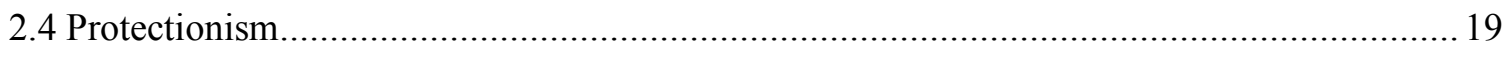

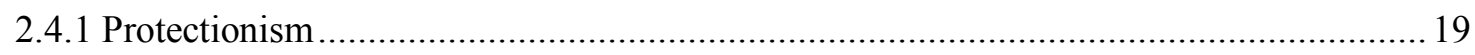

2.4.2 Protectionism and Cross-border Acquisition Completion and Duration....................... 19

2.5 Legitimacy Perspective: Linking Protectionism and Cross-border Acquisition Completion and

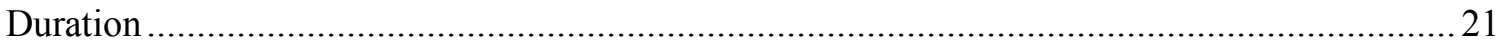

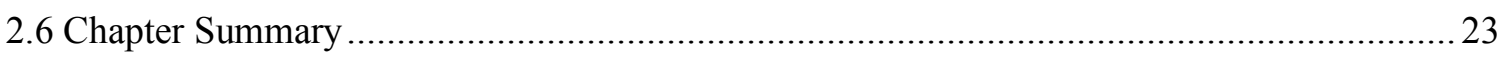

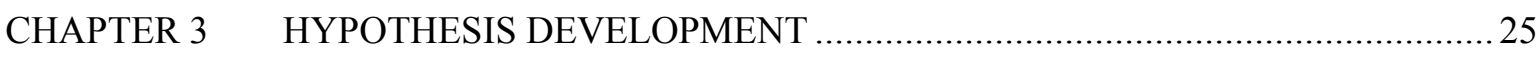

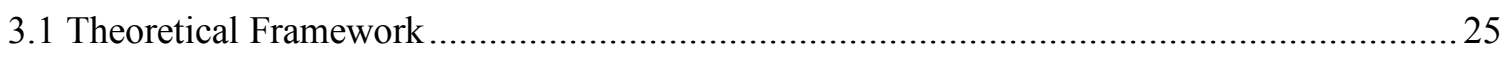

3.2 Hypothesis 1: The Effect of Protectionism on Cross-border Acquisitions .......................... 26

3.3 Hypothesis 2: The Moderating Effect of Target Firm Size................................................ 28

3.4 Hypothesis 3: The Moderating Effect of Target Firm Performance ................................... 28

3.5 Hypothesis 4: The Moderating Effect of Target Firm National Security Concern................ 29

3.6 Hypothesis 5: The Moderating Effect of Host Country GDP Growth................................. 30

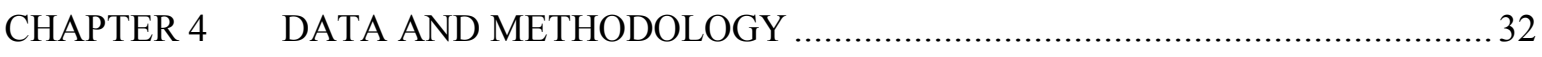

4.1 Sample Selection and Data Collection Process ............................................................. 32

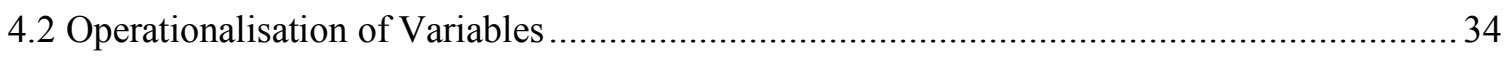

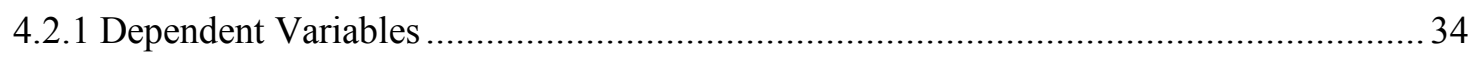


4.2.3 Moderating Variables 37

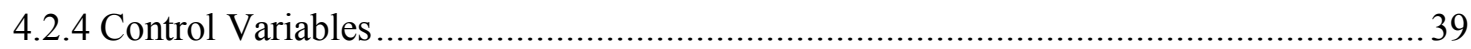

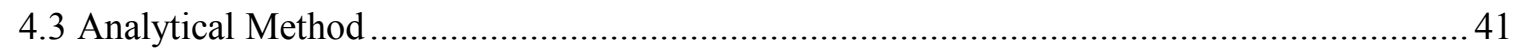

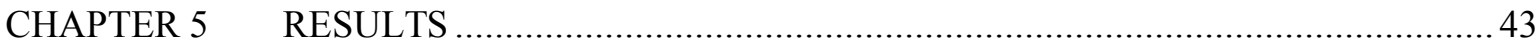

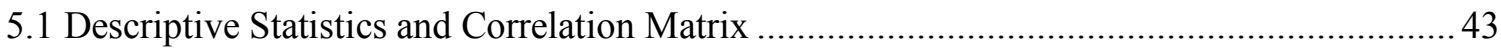

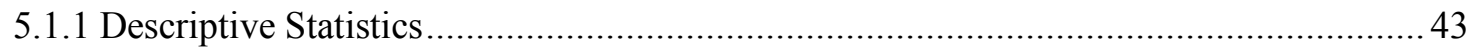

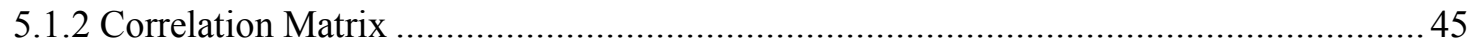

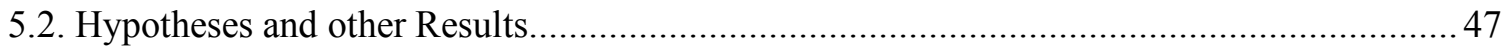

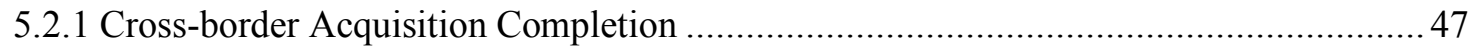

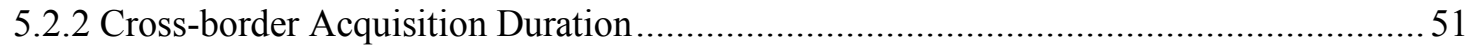

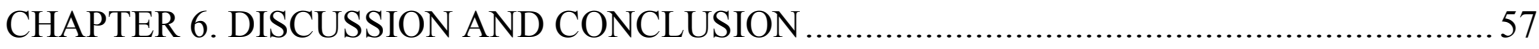

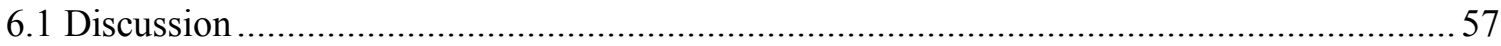

6.1.1 The Effect of Protectionism on Cross-border Acquisition Completion and Duration ..... 57

6.1.2 The Moderating Effect of Target Firm Characteristics .............................................. 58

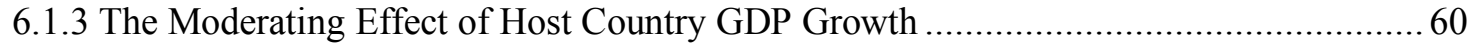

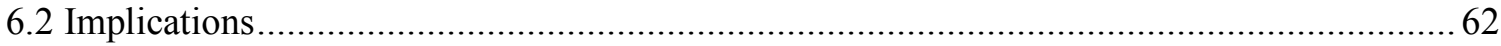

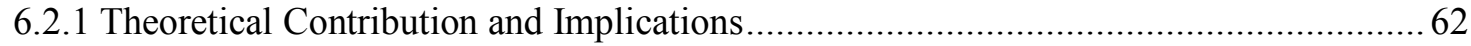

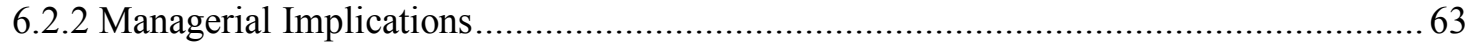

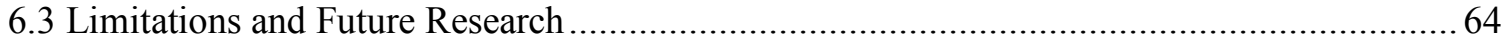

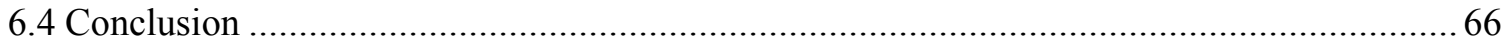

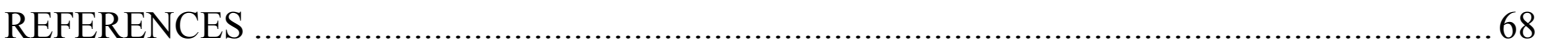




\section{List of Tables and Figures}

\section{Tables}

Table 4.1 Descriptive Statistics of Sample: Number of Cross-border Acquisitions Completed/Withdrawn and Protectionist Actions...............................43

Table 4.1.1 Descriptive Statistics of Cross-border Acquisition Completion: Number of Acquisitions Completed and Protectionist Actions...................................44

Table 4.1.2 Descriptive Statistics of Cross-border Acquisition Duration: Acquisition

Duration in Days and Number of Protectionist Actions.............................45

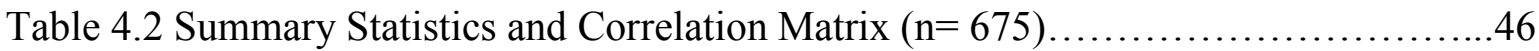

Table 4.3 Logistic Regression Model Cross-border Acquisition Completion Results......48

Table 4.4 Poisson Regression Model Cross-border Acquisition Duration Results..........53

\section{Figure}

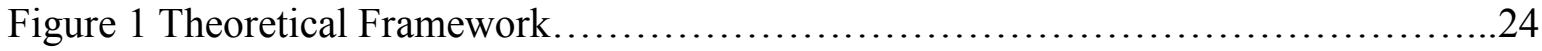




\section{CHAPTER 1 INTRODUCTION}

\subsection{Background}

Recent evidence suggests that cross-border activities are hindered by the protectionist conduct of the governments of prospective host countries (Dinc \& Erel, 2013; Wan \& Wong, 2009; Zhang \& He, 2014; Aktas, Bodt \& Roll, 2007; Heinemann, 2012; Stevens, Xie \& Peng, 2016). Protectionism is "the practice of employing economic devices to restrict or distort trade and to benefit domestic producers" (Hughes \& O'Neill, 2008, p. 170). In other words, it is a preference for natives over foreigners which involves some degree of institution-borne intervention (Hughes \& O'Neill, 2008; Dinc \& Erel, 2013; Enderwick, 2011). Discussion of an increase in protectionism and the related consequences is not confined to scholarly research (Bertrand, Betschinger \& Settles, 2016; Heinemann, 2012; Stevens et al., 2016). It is echoed in media reports and visible in foreign investment statistics (White, 2005; Shin, 2009; UNCTAD, 2017). Despite the recent rise of protectionism and the potential for severe implications on the internationalisation of firms (Zhang \& He, 2014), the influence of protectionism on firms' cross-border activities is underrepresented in the management and international business literature. In particular, there is limited understanding of the conditions under which the impact of protectionism is amplified or reduced.

Cross-border acquisition activity has continued to increase during the past decades. The value of cross-border mergers and acquisitions (CBMAs) surged from USD \$229 billion in 1995 to USD $\$ 721$ billion in 2016 (UNCTAD, 1996; 2016). Protectionism tends to be most evident in the context of cross-border acquisitions (Dinc \& Erel, 2013; Aktas et al., 2007). Acquisitions are "often perceived to be an aggressive move and a potential threat to the economic and political interests of a country" relative to other entry modes (Bertrand et al., 2016, p. 2074). An acquisition confers immediate ownership. The speed at which controlling benefits can shift to a foreign entrant through acquisition may be perceived as a threat by some host country governments (Xie, Reddy \& Liang, 2017). The acquisition of a domestic target by a foreign acquirer may, for instance, incite concern about dependency on a foreign-supplier, the transfer of strategic expertise or the reduction of local employment (Moran, 2013). If the host country sees its interests affected, foreign acquirers may have to 
contend with undue regulatory scrutiny which makes it difficult to complete an acquisition, and to do it quickly (Heinemann, 2012). Deal abandonment and prolonged takeover processes represent substantial costs for firms entering acquisition negotiations (Dikova, Sahib \& van Witteloostuijn, 2010; Luo, 2005). Despite this, the impact of protectionism on cross-border acquisitions is strikingly under-researched (Aktas et al., 2007; Dinc \& Erel, 2013; Zhang \& He, 2014).

In this thesis, I study protectionism: a macro, national-level component of the political institutional environment, and its effect on the outcome of cross-border acquisitions. Specifically, how the likelihood of completion and the duration (days between announcement and completion) of cross-border acquisitions are affected by the degree of protectionism demonstrated by host country institutions.

Host country government agencies "often have the ultimate authority to decide whether and when to approve an acquisition proposal" (Li, Xia \& Lin, 2017, p. 1917). Protectionism is typically demonstrated through acts of arbitrary government intervention (Dinc \& Erel, 2013; Reddy, Xie \& Huang, 2016; Wan \& Wong, 2009). This intervention is often justified as being necessary for the protection of imprecisely defined national security interests (Bertrand et al., 2016; Heinemann, 2012) and can render cross-border market entries difficult, if not impossible. This link between cross-border market success and protectionist government behaviour underscores the relevance of protectionism within the international business domain.

Per UNCTAD's (2016) investment report, national investment policy continues to be geared towards the liberalisation of trade. 71 percent of new inflow policy pertains to the promotion of investment and only 13 percent of new policy comes under the restrictive category. However, the report also notes that "nationalist interest considerations" have gained prominence in investment policy. Nationalism is "a set of policies emphasizing domestic economic activities and unified national interests" (Enderwick, 2011, p. 326). There is not a coherent theory underpinning nationalism, rather the concept is associated with a particular set of attitudes. One of which is protectionism (Zhang \& He, 2014; Enderwick, 2011). These new pieces of policy and extended investment review procedures 
afford governments greater discretion to rule against foreign acquisitions; irrespective of whether the investment policy in force is liberal or restrictive. Research evidence supports the exploitation of "national interest considerations" to thwart contested foreign acquisitions (Dinc \& Erel, 2013; Wan \& Wong, 2009). Despite the European Union (EU) possessing some of the most liberal trade flow policies in the world, Dinc and Erel (2013) found robust evidence of economic nationalism towards foreign acquisition attempts within a group of EU countries.

Although the literature has made substantial progress in providing institutional explanations for cross-border acquisitions, it has tended to focus on the determinants of the: choice of acquisition as an establishment mode (e.g., Meyer, Estrin, Bhaumik \& Peng, 2009), choice of equity control in target ownership (e.g, Moschieri, Ragozzino \& Campa, 2014), target firm selection (e.g., Angwin, 2001), incidence of acquisitions (e.g., Wilson, 1980) and the performance of newly consolidated firms (e.g., Very, Lubatkin, Calori \& Veiga, 1997; Morosini, Shane \& Singh, 1998; Vermeulen \& Barkema, 2001). Researchers have generally not considered the effect of institutions on acquisitions after they are announced, but before they are completed (i.e. during the intermediary stage). It appears that whilst countries tend to encourage inflows of greenfield investments through direct subsidies and favourable legal regimes, it is not uncommon for foreign acquirers to face resistance when attempting to acquire domestic firms (Enderwick, 2011; Heinemann, 2012; Conybeare \& Kim, 2010). Cross-border acquisitions are more susceptible to the influence of protectionism in a host country during the intermediary stage because their announcement is likely to arouse unwanted regulatory attention (Globerman \& Shapiro, 2009; Meyer, Ding \& Zhang, 2014; Zhang, Zhou \& Ebbers, 2011; Conybeare \& Kim, 2010). Whilst a preference for domestic over foreign ownership is typically only present in the context of "national security" industries, in some cases "governments seem to perceive a general threat with any takeover from abroad" (Heinemann, 2012, p. 843). Despite increasing anecdotal evidence of protectionist government behaviour thwarting announced acquisitions by foreign acquirers, empirical research that studies the direct relationship between host country protectionism and cross-border acquisition attempts is scant (Aktas, Bodt \& Roll, 2007; Dinc \& Erel, 2013). 


\subsection{Research Question and Objectives}

The two research questions guiding this study are: (1) what effect does the degree of protectionism in a host country have on a cross-border acquisition attempt? Specifically, how is the likelihood of completion and the duration (days between announcement and completion) of cross-border acquisitions affected by the degree of protectionism demonstrated by the host country institutions and (2) what are the boundary conditions at the firm and national levels that reduce or increase the costs associated with protectionism for cross-border acquisitions? This study investigates whether and how, protectionism affects the outcome of cross-border acquisition attempts. Protectionism within the context of this study is defined as "the practice of employing economic devices to restrict or distort trade and to benefit domestic producers" (Hughes \& O’Neill, 2008, p. 170). Specifically, I argue that the degree of protectionism in a host country has a significant effect on the likelihood of completion and the time lapse between the announcement and the completion of a cross-border acquisition.

Based on a review of the cross-border acquisition and institution-based research, I propose that where the political institutions of the host country demonstrate high protectionism, acquisitions are less likely to go ahead, and the time taken to close an acquisition deal increases. In addition, I test firm and national level boundary conditions to identify which firms are the most gravely affected, and under what conditions the adverse effects of protectionism may be reduced. This study makes three main contributions. First it builds a contingency theory for how national-level protectionist behaviour in a host country may influence the success of the internationalisation of multinational firms. The identification of boundary conditions of the phenomenon, particularly at the target firm level, will aid future researchers in extending the literature. Relatedly, the boundary conditions help to identify legitimacy concerns as a key mechanism that links protectionism to cross-border acquisition completion and duration. Second, in directly studying the impact of protectionism on cross-border acquisitions, the study contributes to the pre-completion acquisition phase literature by introducing the under-researched area of protectionism. In doing so, the study sheds light on the under-researched area of the behaviour of institutions and links it with firm internationalisation strategy. Hence, the research objectives are: 
i. To test the impact of host country protectionism on cross-border acquisition completion likelihood and duration.

ii. To test if the effect of host country protectionism is moderated by target firm characteristics.

iii. To test if the effect of host country protectionism is moderated by the economic condition of the host country.

\subsection{Structure of the Study}

Following this introduction, the study provides a review of the relevant literature in Chapter 2. The chapter lays out the theoretical background underpinning this study. It reviews literature on cross-border acquisition completion and duration, the institution-based view, political institutions, legitimacy and protectionism. Chapter 3 presents the conceptual framework and the arguments supporting the five hypotheses. Next, Chapter 4 contains the research methodology. It details the sample and data collection processes and then explains the variable operationalisation and the statistical methods applied in this study. Chapter 5 reports the descriptive statistics and the correlation matrix. This is followed by the results of the hypotheses testing. Finally, this study concludes with a discussion of the results, research and managerial implications, limitations and suggestions for future research in Chapter 6. 


\section{CHAPTER 2 LITERATURE REVIEW}

This chapter reviews the literature on the key concepts and theories for this study, i.e. crossborder acquisition completion and duration, protectionism, the institution-based view, and in particular, the legitimacy-based view.

\subsection{Cross-border Acquisitions}

A cross-border acquisition is defined as an acquisition "involving an acquiring firm and a target firm whose headquarters are located in different home countries" (Shimizu, Hitt, Vaidyanath \& Pisano, 2004, p. 309). Knowledge of cross-border acquisitions has great importance for firms and researchers alike. Acquisitions are an important entry mode in firms' internationalisation process (Xie et al., 2017). Cross-border acquisitions are a strategically attractive entry-mode because they facilitate quick access to new markets, resources and capabilities (Shimizu et al., 2004). In 2016 cross-border acquisitions accounted for 50 percent of FDI inflows worldwide (UNCTAD, 2017). The popularity of

the entry mode has stimulated a growing number of studies which investigate its success factors.

It is important to adopt a process view on acquisition activities. Researchers have been calling for more explicit consideration of the acquisition process (Bertrand et al., 2016; Jemison \& Sitkin, 1986). The acquisition process consists of two phases (Boone \& Mulherin, 2007; Hansen, 2001). The first period has been termed the "private takeover phase", during which the target (seller) considers various bidders and preliminary agreements are exchanged. After bargaining and negotiating with all interested bidders, the target selects one bidder (the acquirer) and only this firm continues to participate in the cross-border acquisition process. This stage culminates in the winning bidder and target's press announcement of the deal. From this point onwards, the "public takeover phase" or intermediary phase begins, and the parties must renegotiate the initial contract to a satisfactory end (Dikova et al., 2010).

Cross-border acquisition studies can be organised into three streams according to what stage of the acquisition process is under investigation: pre-announcement, pre-completion or post-completion. Pre-announcement studies tend to examine the determinants behind 
equity control in target ownership (e.g, Moschieri et al., 2014), target firm (e.g., Angwin, 2001), or host country selection (i.e. explaining the volume of acquisitions inbound to a country) (e.g., Erel, Liao \& Weisbach, 2012; Wilson, 1980). The pre-completion literature scrutinises the factors which contribute to the completion (deal resolution) or abandonment of the announced acquisition (e.g., Dikova et al., 2010; Li et al., 2017). Post-completion cross-border acquisition research hones in on the determinants of the performance of newly consolidated firms (e.g., Very et al., 1997; Morosini et al., 1998; Vermeulen \& Barkema, 2001).

For the most part, cross-border acquisition studies have focused on the financial performance of post-completion entities (Dikova et al., 2010). Much of the literature on this stage of the acquisition process is rooted in the finance or law literatures and addresses the issue of abandonment in terms of how to make deal completion more likely (e.g., termination fees, lock up provisions, etc.) (Dikova et al., 2010). A gap remains in our knowledge regarding why deals fail following the initial bid. It would thus be of interest to identify the deal-breakers of cross-border acquisition attempts.

\subsection{Cross-border Acquisition Completion and Duration}

Deal abandonments and prolonged takeover processes are associated with substantial costs for firms engaging in cross-border acquisitions (Dikova et al., 2010). For example, a unilateral abandonment of an announced acquisition often incurs a severe penalty for breach of contract (Luo, 2005). Further, the stigma arising from deal abandonment can injure a firm's reputation and credibility for future transactions (Luo, 2005). From the acquirer's perspective, a failed acquisition attempt renders the investments in the crossborder acquisition null. The expense of searching for a suitable target, as well as the cost of lodging the initial offer are lost. Furthermore, competitors may be able to derive an acquirer's intent and long-term deployment strategy from the announcement information and sabotage future efforts towards its enactment (Zhou, Xie \& Wang, 2016).

Regarding duration, the greater the period between the announcement and effective dates, the more managerial attention is diverted from other opportunities, which is especially detrimental where the acquisition falls through (Dikova et al., 2010). From the target's 
perspective, publicising the intention to relinquish firm ownership but not following through on it is likely to compromise business continuity because of employee agitation and abrupt customer churn (Lim \& Lee, 2017). For these reasons, it is imperative that the causes of cross-border acquisition deal abandonments and extended durations are better understood. Although considerable research has focused on cross-border acquisitions, rather less attention has been paid to the pre-completion stage of the takeover process (Boone \& Mulherin, 2007) within which the determinants of cross-border acquisition completion and duration are explored.

A number of empirical studies have investigated the determinants of cross-border acquisition completion and duration. Cross-border acquisition success and failure, in terms of completion or abandonment, has been an increasingly important topic in recent acquisition research (Zhang, Zhou \& Ebbers, 2011). For example, Dikova, Sahib and van Witteloostuijn (2010) studied how the differences between the home and host's countries formal institutions and informal institutions affect cross-border acquisition completion and duration. They found that institutional distance explains part of the variation in the likelihood that a cross-border acquisition will be completed, and formal institutional distance (in terms of expropriation risk) extend the duration of the deal-making. Zhang and He (2014) studied the impact of economic nationalism on cross-border acquisition completion. The authors found that if a cross-border acquisition was deemed safe and helpful for the host country's development it was more likely to reach completion after announcement (and vice versa).

The institution-based view has provided key insights for our understanding of cross-border acquisition completion and duration. The findings of several recent studies identified a number of institutional factors that affect cross-border acquisition completions and durations such as institutional distance or quality (Dikova et al., 2010; Zhang et al., 2011), country risk (Lim \& Lee, 2017), government resistance (Wan \& Wong, 2009; Reddy, Xie \& Huang, 2016; Zhang \& He, 2014; Dinc \& Erel, 2013), bilateral country relationships (Bertrand et al., 2016), national security concerns (Zhang et al., 2011; Zhang \& He, 2014), industry relatedness (Lim \& Lee, 2016), ownership structure (Li et al., 2017), deal motives (Lim \& Lee, 2016) and attitudes (Rowoldt \& Starke, 2014). A couple of exceptions to this 
generalisation are Faelten, Gietzmann and Vitkova's study (2015) which uses an information-economics model to demonstrate the positive influence of institutional investors on completion and Chen, Han and Zeng (2017) who examine the impact of corporate financial hedging on deal completion, duration and performance.

In the following sections, I will review the basic elements and arguments of the institutionbased view, paying particular attention to the protectionist behaviour of political institutions in host countries, and linking it with research on cross-border acquisitions.

\subsection{An Institutional Perspective on Cross-border Acquisition Completion and Duration}

The institution-based view is an important theoretical lens through which to examine crossborder acquisition completion and duration. The relevance of this research stream is that it

firstly, identifies context as influential. Secondly, that it appreciates that "organizations involved in international transactions encounter environmental complexity" (Dikova et al., 2010, p. 226). This complexity varies in accordance with organisations' ability to decipher the "rules of the game" (North, 1990). Applying this perspective to cross-border acquisitions, specifically their completion and duration, enables researchers to focus on the behaviour of the institutional bodies that play a role in devising these rules. This interrelationship between the behaviour of institutions and organisations conducting crossborder acquisitions is especially important given that host country institutions often see their interests affected by foreign acquisitions, more so than with other entry modes (Heinemann, 2012).

\subsubsection{The Institution-Based View}

Institutions are defined as "the humanly devised constraints that shape human interaction" (North, 1990, p. 3). North's (1990) contention that a firm's success and its attainment of favourable acquisition outcomes is determined in part by "the governance structure of the broader environment" has informed the theoretical direction of numerous studies (Dikova et al., 2010, p. 224). North defines formal constraints as including constitutions, laws and property rights (e.g., contracts). Informal constraints are the "sanctions, taboos, customs, 
traditions and codes of conduct" that are characteristic of an environment (North, 1991, p. 97).

These institutions reduce uncertainty by conferring the "rules of the game" onto the organisations within the environment. According to North (1990), organisations are limited in their capacity "to process, organize, and utilize information" and thus, institutions exist not to restrict economic activity but to "simplify the process" of the activity (North, 1990, p. 25). Institutions are specific to environments and thus, the "rules of the game vary across national borders" (Dikova et al., 2010, p. 226). Transactions taking place across borders face an extra layer of complexity because firms must not only decipher an environment but, an unfamiliar one.

Scholars have explained various determinants of cross-border acquisitions by referring to the three-pillar framework (regulative, normative and cognitive) conceived in the sociology discipline by Scott (1995). However, scholars do not typically investigate their simultaneous effects, more often opting to focus on them singularly or in pairs (Ang, Benischke \& Doh, 2015). North's (1990) political economy of institutions and economic behaviour has also provided a theoretical basis to numerous studies (Dikova et al., 2010; Zhang, He \& van Gorp, 2017; Popli, Akbar, Kumar \& Gaur, 2016; Zhou, Lan \& Tang, 2016; Zhou, Xie \& Wang, 2016; Zhang \& He, 2014; Zhang, Zhou \& Ebbers, 2011; Popli \& Kumar, 2016).

\subsubsection{Institutional Differences and Cross-border Acquisition Completion and Duration}

Building on the institution-based view, researchers have examined how institutional differences influence cross-border acquisitions (e.g., Dikova et al., 2010; Zhang et al., 2011). Dikova, Sahib and van Witteloostuijn (2010) propose that the more severe the differences between the home and host's countries formal institutions (in terms of expropriation risk and procedural complexity) and informal institutions (in terms of uncertainty avoidance and power distance), the more likely cross-border acquisition completion will be obstructed or prolonged, because of the acquiring firm's inability or intense difficulty navigating the requirements of the host institutional environment. Dikova 
et al., (2010) findings here indicate that severe differences in the risk of expropriation and contract repudiation lengthen duration. But, contrary to expectations, differences in legal systems and the procedural complexity associated with enforcing contracts were not found to extend duration. Furthermore, the findings of their study did not provide evidence that cross-border acquisition duration is affected by informal institutional distance.

Dikova et al. (2010) did however, find evidence that high formal and informal institutional distance is a barrier to cross-border acquisition completion. In fact, the findings as to whether informal institutional culture distance impairs the "M\&A dialogue" (Xie et al., 2017, p. 152) and thus, completion, are relatively robust across studies (e.g., Popli \& Kumar, 2016; Popli, Akbar, Kumar \& Gaur, 2016; Erel et al., 2012). In the words of Popli et al. (2016), uncertain institutional environments "can provoke negotiation rigidity and intensify the impact of cultural differences" on completion likelihood (p. 407). Whilst Dikova et al. (2010) were the first to bring this finding to light, the article's shortcomings raise two important questions. Firstly, can cultural distance be adequately explained by a single variable? Secondly, does an absolute value of cultural distance between countries offer a fair representation of the extent to which a single variable can capture the construct?

Dikova et al. (2010) touched on these issues, suggesting that "institutional differences might be ameliorated by learning from past acquisition attempts" (p. 232). The issue with their approach was how they chose to capture "learning" to test this proposition: the acquirer's prior cross-border acquisition experience in the focal industry.

An acquirer's "track record of allying with or acquiring other local firms" (Li et al., 2017, p. 1921) or past learnings developed in a similar cultural bloc as the focal deal, have a larger bearing on the effect of cultural distance on cross-border acquisition completion and duration, than cross-border acquisition experience in the focal industry. Popli and Kumar (2016) and Popli, Akbar, Kumar and Gaur (2016) argue an acquirer's cultural experience eases the adverse effect of distance on cross-border acquisition completion and duration by reducing the social uncertainty experienced and improving the acquirer's ability to resolve deadlocks. To conclude, institutional distance affects cross-border acquisition completion and duration but, "the firm itself plays a role in the ramifications of distance" (Zaheer, 
Schomaker \& Nachum, 2012, p. 24). Foreign firms with experience in the host country or in a similar institutional environment will be more skilful in developing tactics for effective communication and negotiation, adopting organisational routines and practices that fit the host institutional environment and overcoming regulatory barriers.

Whilst "cultural differences are endogenous hazards that can be alleviated by the focal firm” (Zaheer et al., 2012; Popli \& Kumar, 2016), firms may be forced to assume a more passive role when addressing formal institutional distance. It is easier to contend with firmlevel issues, such as knowledge deficits and unfamiliarity, than to circumvent adverse formal regulations. This is reflected in the amount of attention researchers spend on formal compared to informal constraints. Furthermore, the argument has been made that the governance quality of a host country is a better proxy for external uncertainty than cultural distance (Slangen \& van Tulder, 2009).

\subsubsection{Formal Institutions and Cross-Border Acquisition Completion and Duration}

The findings emerging from Dikova et al. (2010) on the effect of formal institutional distance on completion are comparable to those of Zhou, Xie and Wang (2016). Zhou, Xie and Wang (2016) also found that the greater the institutional distance, the higher the crossborder acquisition failure rate. Moreover, they took this finding further by investigating whether the relationship between institutional distance and cross-border acquisition failure differs, depending on whether the cross-border acquisitions are inbound or outbound to emerging markets (BRICs). The study shows that institutional distance is less consequential for inbound acquisitions to developed countries' markets. Whilst emerging market acquisitions inbound to developed countries must still exert considerable effort to decipher what formal host country institutions require (because of distance), this process will be easier in a developed country as regulations are far more concrete, comprehensive and transparent compared to those in emerging markets (Zhou, Xie \& Wang, 2016).

Lim and Lee (2017) arrive at the same conclusion - that the direction of the institutional distance matters - but, through a different means. Their study assumes a behavioural perspective on cross-border acquisition completion and duration, relying on disparity in the economic development of the host and home countries to create a context within which the 
decision making of the acquirer can be explored. A high discrepancy in economic development was found to extend duration, while completion likelihood decreased only if the host country was of inferior economic development (Lim \& Lee, 2017). The authors explain this by assuming that regardless of whether or not an announced deal is completed, a decision is made by the acquirer. The outcome of this decision depends on the acquirer's chosen trade-off of risk and return. When the acquirer is from a less developed country, a cross-border acquisition may represent an opportunity to access the superior resources of a developed country. In effect, the expected returns of these transactions are higher, so a higher level of uncertainty is tolerated and thus, there is a higher probability of deal completion (Lim \& Lee, 2017). In other words, less-developed acquirers are more likely to exhibit "a risk-seeking tendency toward the upside potential” (Lim \& Lee, 2017, p. 357). The inverse applies for developed acquirers who exhibit a tendency for risk aversion as they can more accurately predict the likelihood of the expected return. In the same context, industry relatedness and the acquirer's motive for the acquisition (strategic or purely financial) were determined to also effect cross-border acquisition completion and duration, due to their interrelationship with the balance of risk and return embedded in cross-border acquisition decision (Lim \& Lee, 2016).

In the words of Zaheer et al. (2012), "by merely considering the magnitude of difference, rather than the direction of distance, we are in effect positing a relationship whereby it doesn't matter how two entities differ, only how much they differ" (p. 23). Whilst the arguments posed about the effect of institutional distance in Zhou, Xie and Wang (2016) and Lim and Lee (2017) are similar to those in Dikova et al. (2010) - uncertainty confounds success - the former articles offer better insight as to how formal institutional distance matters for cross-border acquisitions. Institutional distance is simply more of a burden when institutional quality is lacking.

A paper authored by Zhang, Zhou and Ebbers's study (2011) proposed that the quality of host country institutions may be a better predictor of cross-border acquisition completion and duration than distance. The researchers found that poor formal institutional quality, in terms of the clarity and enforceability of rules (irrespective of distance), reduced the extent to which acquirers could decipher what institutions imposed upon them. This in turn 
reduced completion likelihood and increased duration. As might be expected, it is difficult to win an announced acquisition, and do it quickly, if you do not know the rules of the game. A second key argument for the quality of institutions, is that they "imply strong legal enforceability, which will protect the interests of acquisition parties involved and reduce costs due to information asymmetry" (Zhang et al., 2011, p. 228).

Extreme distance in formal institutions and the absence of clear institutional rules gives rise to the same outcomes: the acquiring firm struggles with deciphering rules, faces more complexity and then implements poorly-formed strategies for addressing institutions, which leads to an extended duration and in some cases, termination. This environmental uncertainty is compounded by the uncertainty of the deal itself. The public takeover phase represents the first opportunity for acquirers to evaluate whether their target selection has been appropriate. This stage involves engaging with the details of the consolidation and release of new information (i.e. unanticipated challenges), which alter the risks and expected return of an announced acquisition. The ability of each party "to renegotiate the initial contract to a satisfactory end" (Dikova et al., 2010, p. 226), is a key determinant of cross-border acquisition completion likelihood and duration (Zhou, Xie \& Wang, 2016; Hotchkiss, Qian, \& Song, 2005). When entering a host country via acquisition, firms are not only exposed to challenges stemming from the cultural and economic environments as well as the deal itself, but also the political context (Boddewyn \& Brewer, 1994). The influence of host country political institutions on international business has been extensively discussed (e.g., Boddewyn \& Brewer, 1994; Holburn \& Zelner, 2010; Bertrand et al., 2016).

\subsubsection{Political Institutions and Cross-border Acquisition Completion and Duration}

Political institutions have become an important aspect of institutionally-driven enquiries (Wan \& Wong, 2010). Citing Henisz (2000), the role of political institutions is determined by a "government's ability to credibly commit not to interfere with private property" (p. 2). If a transaction triggers national security concerns, regulatory interference tends to increase, and the pre-acquisition stage becomes more politicised (Wan \& Wong, 2009). Political institutions can contribute to acquisition abandonment by pushing uncertainty in the investment environment beyond a manageable risk threshold (Wan \& Wong, 2009; Reddy, 
Xie \& Huang, 2016). Reddy et al. (2016) produced qualitative evidence indicating that “government officials' erratic nature and ruling political party intervention have detrimental effects on the success of Indian-hosted cross-border deals" (p. 917).

Many recent studies indicate that firm-level characteristics such as state-ownership or a target firm's classification in a "sensitive industry" affect cross-border acquisition completion and duration (Zhang et al., 2011; Zhang \& He, 2014; Li et al., 2017). According to Zhang et al. (2011), these firms deal with increased "institutional stringency" (p. 228). In Li et al. (2017) this scrutiny is termed "theorisation": a process whereby regulatory agencies simplify and legitimise (or not) the activities of organisations (acquirers). Whether the foreign acquirer was government owned or not was used to draw in political institutions on cross-border acquisition completion and duration. The authors theorised that where the foreign acquirer was state-owned, the point at which an acquisition raised legitimacy concerns was lower. In other words, where the acquirer is state-owned, acquisition attempts are more likely to arouse negative scrutiny from host institutions leading to incomplete or lengthy cross-border acquisitions. Their findings support those of Zhang et al. (2011) indicating that acquisitions may be deemed less desirable or appropriate (and thus rejected or delayed), when regulatory institutions perceive them to be a source of national security. In both studies, national security concerns arise for institutional reasons: either the acquirer is state-owned and has an implied close affiliation with its domestic government, or the acquirer targets a "sensitive" or essential infrastructure industry thereby creating political implications. Foreign acquirers are often exposed to political difficulties caused by the involvement of the prospective host country's regulatory institutions in the cross-border acquisition process (Bertrand et al., 2016).

\subsubsection{Regulatory Institutions and Cross-border Acquisition Completion and Duration}

Empirical research shows that the completion of acquisitions by state-owned acquirers is disadvantaged for a number of reasons. Firstly, their implicit affiliations with their domestic governments provoke national security concerns (Cui \& Jiang, 2012). Where a foreign government is the ultimate owner, maximum discretion is typically afforded to host institutions to ensure target firms are not acquired for non-commercial purposes, such as to carry out political agendas on behalf of their home governments (Cui \& Jiang, 2012; 
Globerman \& Shapiro, 2009). Such a concern is justified, considering that state-owned firms exhibit a higher degree of receptivity to pressure from their home-country governments than their non-state-owned counterparts (Chung, Xiao, Lee \& Kang, 2016, p. 209). Secondly, "state-owned firms are typically perceived to be less efficient or competitive than their private counterparts" and thus, perceived as "less likely to organize the acquired targets efficiently or to generate spill over benefits to the local business community" (Li et al, 2017, p. 1918). Finally, it has been established that "free-market host societies" are more likely to contest cross-border acquisitions by state-owned firms because they "prefer the government to play a limited role in firm activities" (Li et al., 2016, p. 1918). The logic behind why state-owned firms more often result in rejection or delay is consistent, however actual results have varied.

Zhang et al. (2011) found evidence that government ownership reduces the likelihood of acquisition completion. In contrast, Li et al. (2017) did not find evidence that government ownership reduces the likelihood of acquisition completion, however the acquiring firm being state-owned was found to affect the duration of the acquisition by adding an average of 22 days to duration. Both studies formulated this argument under the assumption that these acquisitions pose legitimacy concerns and thus, arouse negative attention from host institutions which leads to reduced completion and prolonged duration. The extent to which the relationship in a country dyad is amicable is also relevant in this discussion. This implies that there are additional forces beyond state-ownership that politicise the crossborder acquisition process. Bertrand et al. (2016) propose that firms will experience differing results based on their nationality because of the cooperative, or conflictual nature of their country's relationship with the host nation. Further, if the acquiring firm's home institutional make-up is dissimilar from that of the target's, its acquisition bid is likely to be considered more of a threat to the host state's political and economic interests and therefore, is less likely to be completed.

A similar study conducted by Wan and Wong (2009) examined an acquisition attempt by a state-owned Chinese firm (CNOOC) that was prevented from acquiring the US oil firm Unocal after facing tenacious political resistance. In their statement, they said that "the political environment has made it very difficult for us to accurately assess our chance of 
success, creating a level of uncertainty that presents an unacceptable risk to our ability to secure this transaction" (White, 2005). The findings underscored (foreign) nationality as creating a perceived risk to national security because of the poor state of the relationship between China and the US. Further, as a government-backed firm (receiving indirect subsidies), CNNOC was argued to be at an unfair funding advantage relative to other domestic players. CNOOC was overwhelmed with procedural bureaucracy and withdrew its bid (Wan \& Wong, 2009). In part, as a response to the public outcry over CNOOC's bid, legislation has since been enacted in the US which permits particularly rigorous reviews of foreign investment (Foreign Investment and National Security Act of 2007 or FINSA). According to Zhang et al. (2011) the regulatory processes which play a role acquisition abandonment are often reinforced by public opinion and other informal (cognitive and normative) institutional processes.

Cross-border acquisition review procedures may well reduce activity, but it remains an open question whether the laws which preside over the entry mode are implemented in such a way as to reduce foreign acquisitions more than domestic ones (Conybeare \& Kim, 2010). Aktas, Bodt and Roll (2007) focus on the genuine role of M\&A regulation in Europe. Building on extant research, they conceptualised M\&A regulation as way for political institutions to protect the competitive position of domestic firms. They propose two tests in a "protectionism hypothesis": (1) are foreign acquirers subject to more regulatory interventions than their domestic counterparts? (2) are local competitors being harmed? Applying these tests to the Unocal case study, the acquisition failure of CNOOC is difficult to explain as anything other than protectionism. Technically speaking, the acquirer's nationality should be of no concern to regulators, provided that the regulators' goal is only to enhance competition (Aktas et al., 2007). Hemphill (2010) cautions that if competition reviews of cross-border acquisitions are "employed capriciously by governments" they may amount to "non-tariff administrative barriers to FDI" (p. 126). There is little evidence to suggest that antitrust activities foster competition (Aktas et al., 2007) but, there is a legitimate risk of governments using these control mechanisms "to exert undue influence" on cross-border acquisition completion and duration (Heinemann, 2012, p. 870). A host country's formal institutions can alter deal conditions in the name of national interests and 
security "even in more liberal economies or in industries that are, per se, unlikely to raise straightforward national security concerns" (Bertrand et al., 2016, p. 2075).

Tingley, Xu, Chilton and Milner (2015) claim that "most legal barriers to foreign M\&As are based on national security considerations [but], objections on these grounds are often vehicles through which to channel other grievances" (p. 27). It would be of interest to ascertain whether governments do misuse formal institutional rules applicable to acquisitions: in sensitive industries, involving state-actors, and which pose legitimate competitive threats. The question remains whether all cross-border acquisitions are susceptible to increased scrutiny by regulatory institutions? And if so, what motivates this scrutiny when there is not a legitimate reason for its existence?

According to North (1990), the role of formal institutions is to reduce uncertainty in interactions (North, 1990). Contrary, to this supposed function, the rules and procedures imposed by formal institutions seem to be evolving for the purpose of arbitrarily restricting cross-border acquisitions. "Uncertainties arise from incomplete information with respect to the behavior of other individuals and organizations." (Dikova et al., 2010, p. 226). Accordingly, the lack of transparency of the host country's intentions toward inbound foreign acquisitions means that these acquirers are disadvantaged because they are presented with incomplete information on what they can expect from host country political institutions. According to Bittlingmayer and Hazlett (2000), this sort of behaviour may arise because the actions of the host country's institutions are aligned with bureaucratic self-interest, political extraction or obtaining private benefits.

One such private benefit is protectionism. Institution-borne demonstrations of protectionism create winners and losers in the market (Boddewyn \& Brewer, 1994). Research which studies the behaviour of these political institutions tackles a pertinent issue considering: the current protectionist tone of foreign affairs, the numerous anecdotal accounts of undue host-government interference and the confusing incongruence between the liberal policies of some FDI locations and their protectionist reactions towards crossborder acquisitions. 


\subsection{Protectionism}

\subsubsection{Protectionism}

According to Hughes and O’Neill (2008), “protectionism is the practice of employing economic devices to restrict or distort trade and to benefit domestic producers" (p. 170). Protectionist behaviour typically involves providing assistance to "domestic industries either by imposing barriers to foreign competitors or by subsidizing or compensating domestic industries in some other way to assist them against international competition" (Hughes \& O’Neill, 2008, p. 168). Within the economics literature, protectionism largely features as the phenomenon for which an explanation is sought (explanandum), rather than the explanatory variable (explanans). Discussions have centered on determinants and the rationales for and against its appropriateness (Enderwick, 2011; Hughes \& O'Neill, 2008). A key defence of protectionism is the idea that unfettered global trade increases dependency on other nations (Hemphill, 2010). In this case, protectionism is argued as being a necessary means for retaining sovereignty. To serve this objective, it may manifest as restrictions in industries considered strategically significant to a country's selfsufficiency for instance, defence or airlines (Enderwick, 2011). A number of studies denounce protectionism as an unfortunate consequence of the global financial crisis of 2008 (Hemphill, 2010) but, its persistence and the incidence of government intervention suggest that economic crises should not shoulder the full extent of the blame, that it "is instead a general phenomenon" (Heinemann, 2012, p. 844).

\subsubsection{Protectionism and Cross-border Acquisition Completion and Duration}

Governments can act in a discriminatory manner against FDI activities (Enderwick, 2011; Heinemann, 2012; Bertrand et al., 2016). It is of key interest to understand why governments choose to act in this way. Researchers are only just beginning to examine cross-border acquisition completion and duration from the perspective of protectionism. Despite the frequency at which it is mentioned (in studies investigating regulatory scrutiny), little progress has been made in ascertaining protectionism's exact role. It is often identified as potential factor or noted as being implicit in the behaviour of host governments. Researchers often introduce "protectionism" with anecdotal evidence, rather than presenting a definitive argument for its presence and its effect on cross-border acquisition abandonment and duration. Contributions to this facet of the cross-border 
acquisition literature have been piecemeal however, there is considerable evidence that announced acquisitions by foreigners result in more unfavorable outcomes than domestic ones (Aktas et al., 2007; Dinc and Erel, 2013; Bertrand et al., 2016; Heinemann, 2012; Conybeare \& Kim, 2010).

A study by Dinc and Erel (2013) demonstrated that in the EU, governments are more likely to support acquisitions by domestic acquirers than by foreign ones. Their study suggested that host country governments prefer "that target companies remain domestically owned rather than foreign-owned" (Dinc \& Erel, 2013, p. 2471). Secondly, it found that this preference manifests as government intervention which directly impedes acquisition completion. Of 218 foreign bids, the government resists 28 (13\%) and supports 7 (3\%) and of 197 domestic bids, the government resists 9 (5\%) and supports 34 (17\%) (Dinc \& Erel, 2013 , p. 2480). Secondly, they indicate that government resistance has an impact on these acquisitions. Of the 37 merger bids that the government resisted, 26 (70\%) eventually failed. Of 41 merger bids that the government supported, only 11 (27\%) failed" (Dinc \& Erel, 2013, p. 2494). This is interesting given the existence of a treaty (within their sample context) which offered no jurisdiction to firms to block acquisitions for reasons of nationality. The same was true in Rowoldt and Starke (2016) who found that governments are more likely to directly intervene in hostile takeovers if the bidder is foreign, and in Zhang and He (2014), who noticed that the review process for foreign investors in China was more demanding for foreign investors than for domestic ones.

Zhang and He (2014) go on to consider protectionism as one of two functions of economic nationalism. Zhang and He (2014) suggest that a nationalistic ideology manifests as protectionism when a cross-border acquisition targets an essential industry or the acquirer is a state-owned enterprise. These deal characteristics provoke concerns around the country's (economic) sovereignty, which then reduces the likelihood of cross-border acquisition completion. The inclination towards protectionism is suppressed and government responses to cross-border acquisitions take a more liberal (and thus, pro-cross-border acquisition) stance when the bilateral country relationship is good or the host government has reason to believe the deal will produce some net benefit or positive spill over such as technology gains or the restructuring of a poorly-performing firm (Zhang \& He, 2014; Heinemann, 
2012). Durations are also shorter for announced deals of this kind because they are considered safe and conducive to the host country's interests. On the other hand, scrutiny (of the damaging kind) has been found to increase if the target firm under acquisition is financially distressed (Conybeare \& Kim, 2010). In light of this, if the acquirer's intention is to restructure a poorly performing (financially distressed firm), they must be overt when communicating their ability to do so in order to avoid failure due to protectionism.

Unfortunately, the results of this study cannot be taken as evidence for a negative effect of protectionism on acquisition outcomes. The authors use the decisions of regulatory institutions on national security, national growth strategy, and foreign relations to capture the ideology; not the activity. They did not distinguish between a protectionist ideology and actual protectionism. There are two possible ways of handling this problem. Firstly, researchers could provide confirmation that protectionist ideology is correlated with actual acts of protectionism (Dinc \& Erel, 2013). The second route would be to connect protectionist actions to their consequences. Despite this shortcoming, Zhang and He's (2014) findings were like those of Dinc and Erel (2013) and Reddy et al. (2016). Host country institutions react with protectionism, unless the deal is perceived to provide technological, capital or restructuring benefits to a poorly-performing target firm. This may be one explanation for why state-owned firms experience poor outcomes. State-owned firms are typically perceived as being inefficient (Globerman \& Shapiro, 2009; Li et al, 2017) and thus, not as able to provide the aforementioned benefits and not spared from protectionism. "Despite ample evidence of a protectionist attitude against foreign acquirers, we still know very little about what drives government intervention in the host market and about the implications that this can have for the pre-acquisition process" (Bertrand et al., 2016, p. 2075). What is clear is that studies that theoretically link and empirically test the relationship between protectionism and cross-border acquisition attempts, are slim in number.

\subsection{Legitimacy Perspective: Linking Protectionism and Cross-border Acquisition} Completion and Duration

Researchers applying the institution-based view have typically employed the construct of legitimacy and follow Suchman (1995) in defining legitimacy as "a generalized perception 
or assumption that the actions of an entity are desirable, proper, or appropriate within some socially constructed system of norms, values, beliefs, and definitions" (Suchman, 1995, p. 574). Legitimacy with regulatory agencies and government actors is a "commonly studied type of legitimacy" (Bitektine, 2011, p. 56). Suchman (1995) describes three types of legitimacy: pragmatic, moral and cognitive (1995). Pragmatic legitimacy "rests on the selfinterested calculations of an organization's most immediate audiences" (Suchman, 1995, p. 578). A firm's actions will achieve pragmatic legitimacy if they are perceived to be "contributing value to a legitimacy-conferring stakeholder, directly or indirectly" (Stevens et al., 2016, p. 948). Drawing on the arguments detailed in Zhang and He (2014), this value may provide the opportunity to absorb tacit knowledge that leaks into the environment post-acquisition. Conversely, an organisation's actions will be pragmatically illegitimate if they are seen as subtracting value from the environment in which they take place: for example, the acquisition of a target firm that is economically significant to the host economy.

The literature has not yet systematically studied the influencers of cross-border acquisition completion likelihood and duration. Especially in environments characterised by host country protectionism. According to Suchman "the multifaceted character of legitimacy implies that it will operate differently in different contexts" (Suchman, 1995, p. 573). Thus, applying a legitimacy perspective leads to a consideration of "the circumstances that form the setting for an event" (Context, n.d.). From this, we can conclude that host country institutions will construct a deal's legitimacy by considering: the nature of the transaction and involved parties, the acquirer's motivations as discerned from their actions and "the implications of the acquisition for national security and economic development" (Li et al., 2017, p. 1919). Prior work suggests that in the case of cross-border acquisitions, the context is in particular "closely tied to a set of conditions associated with both the foreign firms and local targets" (Li et al., 2017, p. 1919).

Whilst, both target and acquirer firm characteristics affect the legitimacy perceived by host country regulatory institutions, analysing target firm characteristics may be a more valuable exercise given the ease of altering target selection criteria compared to altering the firm structure of the acquirer or the external environment (Zhou, Xie \& Wang, 2016). The key 
characteristics of target firms that have been studied in cross-border acquisition studies include: whether the target is public or private (e.g., Li et al., 2017; Dikova et al., 2010; Zhou, Lan \& Tang, 2016; Zhang \& He, 2014; Zhang et al., 2011), subsidiary status (e.g., Dikova et al., 2010), size (e.g., Chari \& Chang, 2009; De Beule \& Duanmu, 2012), profitability (e.g., Bertrand et al., 2016; De Beule \& Duanmu, 2012), state-ownership (e.g., Zhang et al., 2011; Zhang \& He, 2014), subsidiary status (e.g., Dikova et al., 2010; Li et al., 2017), industry classification (e.g., Zhang et al., 2011) and research and development (R\&D) alliances (e.g., Li et al., 2017).

For example, Li et al., (2017), found that a target firm's R\&D alliances strengthen the negative effect of state ownership on acquisition completion. This argument was made under the assumption target firms with more $R \& D$ alliances are likely to be innovators and to possess critical technologies and know-how. The likelihood of completion is reduced for acquisitions involving these target firms because of fears that state-owned foreign firms may pass along transferable technologies to their home countries (Li et al., 2017). Similarly, Zhang et al. (2011) found that the likelihood of acquisition completion depends upon the nature of the target firm's primary industry. Specifically, their results suggest that cross-border acquisitions of target firms in natural resource industries (energy, mining, steel, and material industries) are more likely to be exposed to regulatory pressures which impede completion. These ideas suggest that host country institutions not only consider the acquirer's characteristics when assessing the legitimacy of a deal, but also the target's characteristics.

\subsection{Chapter Summary}

In sum, the above literature review suggests that cross-border acquisition completion and duration are relevant and important phenomena which deserve a more systematic research approach. Secondly, the institution-based view provides crucial insights, but little has been done regarding how the behaviour of political and regulatory institutions can influence these phenomena. Examining the impact of protectionist behaviour of the host country government will be a timely research endeavour. Third, a core concept in the institutionbased view, legitimacy, will provide a useful lens for understanding the mechanism through 
which protectionist behaviour in the host country influences cross-border acquisition outcomes. 


\section{CHAPTER 3 HYPOTHESIS DEVELOPMENT}

\subsection{Theoretical Framework}

I develop a conceptual framework which directly links the degree of protectionism in a host country to the completion likelihood and duration of an announced cross-border acquisition. I propose that cross-border acquisitions are less likely to go through and the time taken to close a deal is longer, where the host country demonstrates strong protectionism. Furthermore, utilising a legitimacy perspective rooted in the institution based view, I have identified four key boundary conditions at the firm and national levels that may attenuate, or exacerbate, the degree of protectionism experienced by prospective foreign acquirers: target firm size, target firm performance, target firm national security concerns, and host country GDP growth.

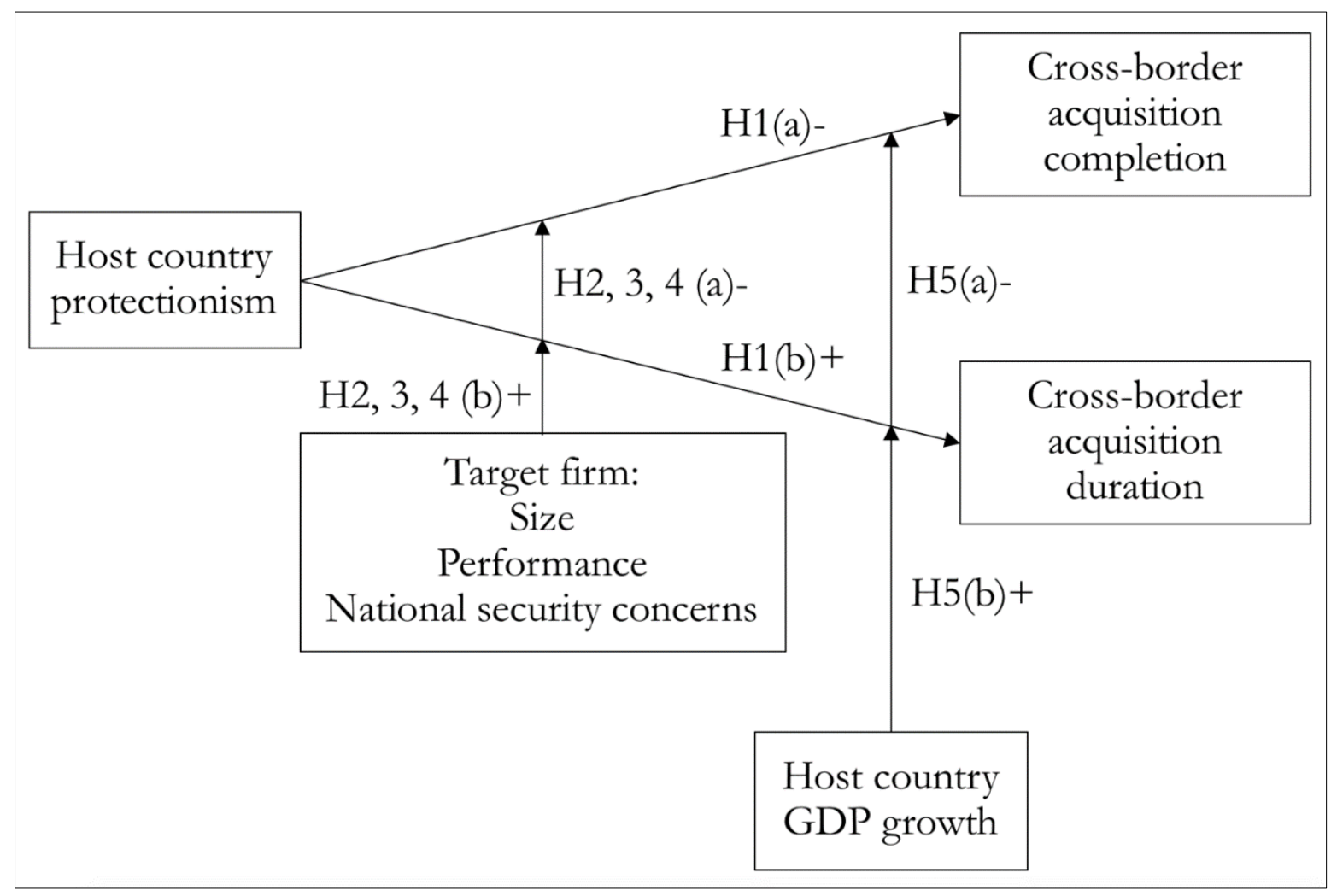

Figure 1. Theoretical Framework

I argue that some deals are more vulnerable to the damaging effect of protectionism than others. The legitimacy of a deal depends on the specific action the acquirer is taking in the host country environment. If the acquirer is pursuing the closure of a deal which raises 
serious legitimacy concerns, it may experience increased scrutiny. I argue that the nature of the target firm under acquisition and the GDP growth of the host country further legitimises or delegitimises a cross border acquisition. The target firm is the scrutinising component, while GDP growth represents the acquisition context (specifically, the implications for economic development in the host country). The target firm's characteristics and the host country's GDP growth may affect the level of legitimacy concerns, thereby altering the proposed relationship between protectionism and cross-border acquisition completion and duration.

\subsection{Hypothesis 1: The Effect of Protectionism on Cross-border Acquisitions}

Acquisitions by foreigners result in more unfavourable outcomes than domestic ones (Aktas et al., 2007; Dinc \& Erel, 2013; Bertrand et al., 2016; Rowoldt \& Starke, 2011). However, this should not be taken to mean that all cross-border acquisitions are subject to special scrutiny. A more accurate statement may be that the relevant host country institutions "use their administrative discretion so as to be less lenient in reviewing such cases" (Conybeare \& Kim, 2010, p. 1180). Many recent studies provide evidence to this effect (e.g., Dinc \& Erel, 2013; Tingley et al., 2015). It is also clear that host government agencies "often have the ultimate authority to decide whether and when to approve an acquisition proposal" (Li et al., 2017, p. 1917). Only acquisitions possess "the permanence, effects on competition or political salience to come under governmental scrutiny" (Conybeare \& Kim, 2010, p. 1177).

Although acquirers are unlikely to place bids without reasonably high expectations that the deal will be completed, the announcement of a cross-border acquisition in no way guarantees its completion (Dinc \& Erel, 2013). After announcement, a cross-border acquisition must endure "reactions from market and different interest groups" as well as passing regulatory scrutiny (Zhang et al., 2011, p. 228). The scrutiny of these authorities can prevent approval processes from proceeding smoothly, hindering the timely completion of the cross-border acquisition. A gap remains in our knowledge regarding what criteria host government agencies use to make this call. Furthermore, why do governments decide to intervene more often when then acquirer is foreign? Applying a legitimacy perspective, the higher the degree to which the government perceives a firm's actions to be "desirable, 
proper, or appropriate", the more legitimate their actions are in the eyes of the government (Suchman, 1995; Li et al., 2017). The less desirable, proper or appropriate the host government perceives the deal to be, the more concerned they will be as to the legitimacy of a deal and thus, the less likely the acquirer will be able to complete the acquisition or do it as quickly as possible.

First and foremost, the foreign nationality of the acquirer influences whether or not the focal acquisition is considered legitimate (Suchman, 1995). Suchman (1995) describes three types of legitimacy: pragmatic, moral and cognitive (1995). Of particular relevance to the completion and duration of cross-border acquisitions is the concept of pragmatic legitimacy. Pragmatic legitimacy "rests on the self-interested calculations of an organization's most immediate audiences" (Suchman, 1995, p. 578). There a number of barriers to achieving pragmatic legitimacy in a foreign acquirer's pursuit of deal closure. One is based on the nature of the mode of entry itself. Critics assert that acquisitions bring lower benefits than greenfield investments (Globerman \& Shapiro, 2012). For an action to be discerned as pragmatically legitimate, it must be "seen as contributing value to a legitimacy-conferring stakeholder” (Stevens et al., 2016, p. 948). Domestic firms are considered "the instruments and intermediary objectives of national policy" (Bertrand et al., 2016, p. 2074). A foreign acquisition may threaten a host country government's ability to influence the activities of the domestic firm in a way that serves its interests (Kim, 2007; Bertrand et al., 2016). Furthermore, the acquired domestic firm could also be overly receptive to the influence of its home country (Chung et al., 2016) and so "potentially pursue diverging interests" i.e. detract value (Bertrand et al., 2017, p. 6).

Drawing on prior research and a legitimacy perspective, I propose that host country protectionism reduces the likelihood of completion or increases the time taken to finalise announced cross-border acquisitions, by inducing regulatory scrutiny which may culminate in some measure of government intervention. I argue that this intervention is motivated by the host country's protectionist inclinations (Dinc \& Erel, 2013; Aktas et al., 2007). "The leeway of governments to act in a discriminatory manner against FDI activities is particularly large" (Bertrand et al., 2016, p. 2074). Should a government's legitimacy concern surpass a certain threshold, government intervention may result in either a coerced 
or voluntary withdrawal of an announced cross-border acquisition bid. Simply put, host governments can play a role in the outcomes of acquisition attempts should they feel it necessary to do so.

Hypothesis 1a: The higher the degree of protectionism in the host country, the lower the likelihood of completion for a cross-border acquisition attempt.

Hypothesis 1b: The higher the degree of protectionism in the host country, the longer the time lapse between the announcement and effective dates of a cross-border acquisition.

\subsection{Hypothesis 2: The Moderating Effect of Target Firm Size}

Within the context of this study, protectionism refers to a preference for domestic acquirers over foreign acquirers. I argue that this preference is heightened when the target firm involved is economically significant to the host economy. Not only are the motivations for quashing a deal more acute in this context but, the scope for public opinion and the government's legitimacy concerns that have a bearing on the transaction are larger. A cross-border acquisition involving a large target is less likely to be determined by a market process, based on the will of the sellers and buyers (Zhang et al., 2011). Thus, a successful acquisition attempt will be more troublesome for a large target than a smaller target (Zhang et al., 2011; Zhang \& He, 2014).

Hypothesis 2a: The negative relationship between the degree of protectionism in the host country and cross-border acquisition completion will be stronger for larger target firms. Hypothesis 2b: The positive relationship between the degree of protectionism in the host country and cross-border acquisition deal duration will be stronger for larger target firms.

\subsection{Hypothesis 3: The Moderating Effect of Target Firm Performance}

Firms seeking to acquire target firms that are economically important may encounter greater resistance from host governments. This reduces the likelihood of a successful acquisition attempt. If an acquirer's actions within the host country are viewed as undesirable, "the government will be considerably more motivated to interfere" (Stevens et al., 2016, p. 952). I examine the effect of the target firm's significance through the construct of performance. I hypothesise that acquirers seeking to purchase high-performing 
target firms will face a similar institutional resistance because of the significance of these firms to their domestic economy (as implied by their profitability).

Hypothesis 3a: The negative relationship between the degree of protectionism in the host country and cross-border acquisition completion will be stronger for higher-performing target firms.

Hypothesis $3 \boldsymbol{b}$ : The positive relationship between the degree of protectionism in the host country and cross-border acquisition deal duration will be stronger for higher-performing target firms.

\subsection{Hypothesis 4: The Moderating Effect of Target Firm National Security Concern}

As formerly discussed, protectionist behaviour is generally enabled where domestic legislation authorises host governments to block deals for reasons of "national security". In addition to competition law, "many countries have laws and regulations that restrict foreign investment in industries considered sensitive to national security or sovereignty" (Toth, 2008; Conybeare \& Kim, 2010). Prior research has underscored (foreign) nationality as creating a perceived risk to national security (Wan \& Wong, 2009). Furthermore, governments can "use national security as the mandate for protectionism and thus, to oppose takeovers of domestic firms by foreigners, even when the shareholders are in support” (Zhang \& He, 2014, p. 215). Moreover, cross-border acquisitions may arouse concern if the operation of the target firm has implications for national security. They create dependencies on foreign-controlled suppliers for crucial goods and services (Moran, 2013; Bertrand et al., 2016). These acquisitions cause a risk of transferring strategic expertise and other sensitive information to foreign governments (UNCTAD, 2016). Governments tend to prohibit or restrict foreign investment in sectors considered crucial to national security, such as "those involving military production, crucial infrastructure, or energy and other scarce natural resources" (Zhang \& He, 2014, p. 215). Thus, we can conclude that where the target firm is within an industry essential to the host country's economy or development (a national security sector) it is more likely to result in fewer completions and longer durations ( $\mathrm{Li}$ et al., 2017). The increased potential for poor acquisition outcomes stems from host government's duty to ensure the nation's security and, thus, its duty to intervene (i.e. quash a deal on the basis of its rights to maintain 
national security) where the foreign control of a domestic firm could compromise its ability to do so (Kim, 2007). Following this logic, I expect that cross-border acquisitions of targets in national security industries may face more obstacles to completion and timely durations because of the extra layer of legitimacy concerns that they add to an already contested FDI mode.

I argue that that the additional presence of national security concerns in this equation intensifies protectionism's impact on acquisition outcomes by allowing easier recourse to protectionism (leaving more room for abuse of legislation). In brief, if a cross-border acquisition also poses national security concerns (legitimate or not), the ability to act in a protectionist manner towards that acquisition increases. National security concerns have been identified as a potential vessel for channelling all manner of concerns (Tingley et al., 2015).

Hypothesis 4a: The negative relationship between the degree of protectionism in the host country and cross-border acquisition completion will be stronger for target firms in an industry with higher national security concerns.

Hypothesis 4b: The positive relationship between the degree of protectionism in the host country and cross-border acquisition deal duration will be stronger for target firms in an industry with higher national security concerns.

\subsection{Hypothesis 5: The Moderating Effect of Host Country GDP Growth}

Researchers have long acknowledged that GDP tends to affect the degree to which a host country is viewed as a desirable investment environment and therefore, may influence entry into a given market (e.g., Erel et al., 2012). It is still unknown how this may affect crossborder acquisitions after this decision is finalised. GDP growth is often used as a proxy for the level of potential benefit an entrant can derive from the FDI location (Xia, Tan \& Tan, 2008). Yet, whether or not a country is an attractive investment environment is irrelevant, if the source of attractiveness plays a role in the failure of the investment i.e. the acquisition attempt, rendering the perceived benefits unattainable. This would suggest that the GDP growth of the host country is of greater relevance in the early phase of the cross-border acquisition process. 
It is reasonable to infer that firms would experience differing levels of protectionism based on the state of the investment environment in the host country (Conybeare \& Kim, 2012). I suggest that low GDP growth may increase the desirability of foreign acquisitions by host regulatory agencies, thereby facilitating prompt completions. Operationalising this logic suggests that weaker performing economies are more likely to desire foreign investment. I argue that this would positively influence the host government's opinion that an acquirer's action is legitimate. Therefore, the host government can accept this action during the acquirer's pursuit of acquisition deal closure. This acceptance precludes the need for intervention which reduces the likelihood that an acquisition attempt would fail or that the duration of the deal would be arbitrarily extended.

Hypothesis 5a: The negative relationship between the degree of protectionism in the host country and cross-border acquisition completion will be stronger in host countries with higher GDP growth.

Hypothesis $5 \boldsymbol{b}$ : The positive relationship between the degree of protectionism in the host country and cross-border acquisition deal duration will be stronger in host countries with higher GDP growth. 


\section{CHAPTER 4 DATA AND METHODOLOGY}

This chapter begins by describing the sample and data collection processes. Next, a description of the variables is presented, followed by the analytical method. To test the five hypotheses, I collected data covering the cross-border acquisitions undertaken by foreign publicly listed firms, that occurred in all manufacturing and services industries (excluding financial services), within the U.S. and Canada between 1995 and 2015 (inclusive).

The purpose of this study is to test for a relationship between host country protectionism and cross-border acquisition completion likelihood and duration. Quantitative research allows researchers to identity patterns of behaviours and draw conclusions from statistical analysis (Ang, 2014). These qualities, support the adoption of a quantitative methodology for addressing the primary research question: what effect does the degree of protectionism in a host country have on a cross-border acquisition attempt? Specifically, how is the likelihood of completion and the duration (days between announcement and completion) of cross-border acquisitions affected by the degree of protectionism demonstrated by the host country institutions.

Secondary data is utilised in this study and has several benefits worthy of mention. Firstly, the study was interested in changes in protectionism over time. The ease of conducting a longitudinal assessment of a phenomenon with secondary data relative to other kinds of data was influential in this decision (Shultz, Hoffman \& Reiter-Palmon, 2005). Second, protectionism tends to be highly politicised (Aktas et al., 2007). It was important that protectionism was measured and collected objectively. Secondary data is "less subject to biases and ambiguity in measurements" (Rabinovich \& Cheon, 2011, p. 303). Furthermore, secondary data is largely recorded in the public sector so comparable firm-level information is easily accessed for analysis. Given the lack of previous scholarship and literature covering the intermediary stage of cross-border acquisitions, testing for statistical relationships between variables constitutes a good first step.

\subsection{Sample Selection and Data Collection Process}

The use of data from the U.S and Canada is appropriate for three reasons. Firstly, I am looking for variation in cross-border acquisition outcomes that can be explained by 
protectionism. These two countries provide an optimal context due to their similarity in formal institutional development. By minimising other institutional differences, I can more easily isolate the effect of protectionism as a subset of the formal regulatory environment. Secondly, these countries are key FDI host economies and boast high inflow figures through means of cross-border acquisitions. In 1995 the U.S. and Canada received USD $\$ 68,026$ million in FDI inflows. 54 percent of this was accounted for by cross-border M\&As (UNCTAD, 1996). In 2015 the U.S. and Canada received USD \$ 389,914 million in FDI inflows. This figure rose to USD \$ 424,825 million (increasing by 8 percent) in 2016 . Almost 90 percent (USD $\$ 372449$ million) of this was accounted for by cross-border M\&As (UNCTAD, 2017). Third, a sample derived from two host countries, spanning twenty years, highlights variation in cross-country and cross-time protectionist behaviour.

The sampling frame is the cross-border acquisition activity undertaken by publicly listed firms in all manufacturing and services industries (excluding financial services), within the U.S. and Canada between 1995 and 2015 (inclusive). Acquisitions among financial services firms are subject to distinctive rules and regulations and therefore, not included in my sample. To explain the role of target firm characteristics, I include only publicly listed firms, for which data can be easily accessed. Acquisitions were included only where the acquirer sought majority control in the target firm. The ownership stake sought may increase the degree to which the host country perceives its interests are threatened and thus, it may play a role in triggering protectionist behaviour (Dikova et al., 2010; Zhou, Xie \& Wang, 2016). Given that the sample comprises only publicly listed firms, firms in this sample are predominantly large. This captures the effect of protectionism because "large and visible cross-border acquisitions are the most likely to be exposed to protectionism, and hence, government interference" (Sauvant, 2009; Bertrand et al., 2016).

Data was extracted from the Securities Data Corporation (SDC) database and then merged with acquirer and target information obtained from Compustat, to produce a refined sample where both deal and firm level data were available. SDC contains deal-specific information on M\&A activity worldwide and is a widely accepted academic data source for acquisition research (e.g., Dikova et al., 2010; Zhou, Xie \& Wang, 2016). Data collected included the dates at which the deal was announced and, effective or withdrawn, and the nationalities 
and industry classifications of the target and acquirer firms. Deal attributes such as percentage sought and the attitude of the transaction were also extracted. Firm-level data was obtained from the Compustat Global and Compustat North America databases. Compustat is a reputed source for firm-level data and has been used extensively by prior research on cross-border acquisitions (e.g., Li et al., 2017; Dinc \& Erel, 2013). Its data includes information on assets and liabilities, revenue, and employee numbers. Finally, country-level data was obtained from the World Bank and Geert Hofstede's (1980) work.

The final sample consists of 675 observations after removing cases with missing data, with 560 cross-border acquisitions inbound to the U.S. and 115 to Canada. Acquirers came from 32 countries ${ }^{1}$. Of the 675 deals, 584 ( 86.5 percent) deals were completed and 91 were withdrawn. Cross-border acquisitions occurred in the following industries (the number of deals is indicated in parentheses): Manufacturing (424), Services, excluding Financial Services (183), Construction (5), and Transportation and Public Utilities (63). Furthermore, these deals took place during the following years: 1995 (22); 1996 (17), 1997 (36); 1998 (44); 1999 (75); 2000 (69); 2001 (32); 2002 (26); 2003 (29); 2004 (24); 2005 (26); 2006 (35); 2007 (45); 2008 (36); 2009 (22); 2010 (23); 2011 (14); 2012 (22); 2013 (15); 2014 (25); 2015 (38).

\subsection{Operationalisation of Variables}

\subsubsection{Dependent Variables}

This study investigates how the degree of protectionism in a host country impacts the completion and duration of an announced cross-border acquisition. A "successful" acquisition (from the perspective of the acquirer) can be defined as one which is completed and, completed in a timely fashion (Lim \& Lee, 2017). The measurement of both crossborder acquisition completion and duration is consistent with previous research (e.g., Dikova et al., 2010; Li et al., 2017; Lim \& Lee, 2017). The data for both dependent variables was sourced from the SDC database.

\footnotetext{
1 Acquirers came from the following countries (the number of deals is indicated in parentheses): Argentina (2), Australia (12), Austria (2), Belgium (8), Brazil (3), Canada (104), China (2), Denmark (6), Finland (12), France (53), Germany (37), Greece (1), Hong Kong (8), India (9), Ireland (14), Israel (20), Italy (9), Japan (24), Mexico (5), Netherlands (38), New Zealand (1), Norway (3), Russia (6), Singapore (5), South Africa (2), South Korea (4), Spain (7), Sweden (18), Switzerland (24), Taiwan (1), United Kingdom (124), and United States (111).
} 


\subsubsection{Cross-border Acquisition Completion}

Cross-border acquisition completion is coded as a dichotomous variable that takes the value of 1 if the deal is listed as complete after its announcement date and 0 if otherwise. Where the acquisition status was unknown (listed as neither completed, nor withdrawn in SDC) a manual search using Factiva and Google was conducted. The acquisition status was recorded based on the outcome of these searches. Deals were removed where the status could not be determined (Li et al., 2017). In summary, 977 cases with completion data were directly identified from SDC, 111 cases were manually searched, and 100 cases were removed due to lack of information.

\subsubsection{Cross-border Acquisition Duration}

Cross-border acquisition duration is the second dependent variable of this study and is defined as the time taken for an acquisition to be completed. It is measured as the difference in days between the announcement date and effective date of an acquisition, consistent with previous studies (Li et al., 2017; Dikova et al., 2010). To address the presence of outliers in the sample, the top and bottom $5 \%$ of values for this dependent variable were winsorised. After additionally dropping " 0 " values and analysing the reduced sample comprised of the remaining cases, the results remained the same. Deals with durations of 0 were dropped because they are more likely to indicate a delay in the public announcement of an acquisition, than an acquisition that was completed on the day of its announcement.

\subsubsection{Independent Variable}

Due to a lack of research on protectionism, there is no established measure of the phenomenon. The measure used in this study is based on the definition that says that protectionism is "the practice of employing economic devices to restrict or distort trade and to benefit domestic producers" (Hughes \& O’Neill, 2008, p. 170). Governments' actions in restricting or distorting trade reflect the overall protectionist tendencies in a country's political institutions and are likely to influence the outcome of foreign cross-border acquisitions(Hemphill, 2010; Baldwin \& Evennett, 2009). I use the number of non-tariff measure (NTM) investigations initiated (per year) as reported by the World Trade 
Organisation (WTO), to capture protectionism in a host country government. NTM initiations reflect a host country's ability to show moderation and restraint (or, a lack thereof) in taking recourse to trade restrictions (WTO, 2017a). These restrictions have been referred to as a "murky" or "low-intensity" protectionism (Baldwin \& Evenett, 2009; Shin, 2009). Such actions "are legal under WTO regulations and do not violate trade agreements", yet still undercut free trade and the effectiveness of growth policies (Shin, 2009; Hemphill, 2010). For the purpose of this study, the initiation of an investigation will be considered a trade-restrictive action towards foreign exports to protect the domestic industry. As such, it represents the employment of an economic device by the host country for the purpose of restricting or distorting trade to the benefit of domestic firms. Accordingly, initiated investigations reflect the presence of protectionism in the host country and thus, are termed "protectionist actions" in this study.

To construct the protectionism measure for each host country in each sample year, I take the number count of investigations initiated in three NTM classifications ${ }^{2}$ : trade defence measures, agricultural measures and other measures (WTO, 2017). Trade defence measures include: anti-dumping (ADP), countervailing duties (CVD), and safeguards (SG). These measures are "trade remedy instruments" designed to address situations where the domestic industry is suffering "injury". If the injury is caused by "dumping", the host government can react by initiating an ADP investigation. The WTO defines dumping as the situation "when goods are exported at a price less than their normal value" (WTO, 2017). If the injury is caused by "subsidies given to producers or exporters in the exporting country", a host government may seek recourse for its domestic market using CVDs (applying duties to foreign goods) to offset the injurious subsidies. Finally, host governments may provide

\footnotetext{
${ }^{2}$ WTO groups NTMs into four classifications. The fourth category is the technical measures classification which includes: sanitary and phytosanitary measures (SPS) and technical barriers to trade (TBT). WTO members are required to notify their intention to introduce new or modified technical measures in order "to enhance transparency regarding measures taken to address legitimate policy objectives" (WTO, 2017a, p. 40). "An increased number of notifications does not automatically imply greater use of protectionist measures, but rather enhanced transparency regarding such measures (WTO, 2017a, p. 37). Accordingly, the technical measure classification has been omitted from the variable.
} 
protection to a specific domestic industry with SGs (a temporary import restriction), if they are suffering because of an "unexpected build-up of imports" (WTO, 2017).

The second classification used in this study is agricultural measures. This grouping contains special safeguards (SSG), tariff-rate quotas (TRQ) and export subsidies (XS). All agriculture measures exist for the purpose of protecting a country's domestic agricultural market. SSGs are import duties used to deal with import surges or price falls. The application of a tariff-rate quota is when quantities inside a quota are charged lower import duty rates. Finally, export subsidies are benefits "conferred on a firm by the government contingent on exports" (WTO, 2017).

The remaining measures are grouped into the classification "other" and include, quantitative restriction (QR) and state trading enterprise (STE) measures. Quantitative restrictions are specific limits (available for a fixed period of time) on the quantity or value of goods that can be imported. Elimination of these restrictions is required by the General Agreement on Tariffs and Trade (GATT) on account of improving market access. The sustained presence of QRs implies the relevant country has not yet committed to avoiding protectionism against foreigners.

The number of all NTMs (notified to WTO) that were initiated by the sample countries for the years 1995-2015 were extracted from WTO's Integrated Trade Intelligence Portal (ITIP) Goods database.

\subsubsection{Moderating Variables}

I investigate the moderating effect of four variables on the relationship between protectionism and cross-border acquisition completion likelihood and duration. The moderating variables are: target firm size, target firm performance, whether the target firm's primary industry tends to cause national security concerns, and the host country's GDP growth.

\subsubsection{Target Firm Characteristics}

\subsection{Firm Size}


The logarithm of the total assets of the firm in the year prior to the acquisition is utilised as a measure for firm size. This data was obtained from Compustat.

\subsection{Firm Performance}

Return on assets (ROA) is the measurement adopted for firm performance. ROA was chosen as this study's measure of performance as it has been proven to be highly correlated with other measures often adopted to represent performance (Keats \& Hitt, 1988). It is expressed as the ratio of net income to total assets in the year prior to the focal acquisition's announcement. A variable for firm performance is included because it is indicative of a firm's significance to its host economy. This data was obtained from Compustat.

\subsection{National Security Concerns}

In line with the concerns of Zhang and He (2014), a variable for target firm's national security concern will be factored into the analysis. I use two industries to capture national security concern in the host country. Using the SIC codes listed by SDC, a dichotomous variable was constructed to test this variable. Where the target firm was in the communication equipment industry (SICs: 3669, 3661, 3663) or the aerospace and aircraft industry (SICs: 3721, 3724, 3728, 3764, 3769) the deal was coded as 1 and 0 for otherwise. Foreign control of infrastructure and strategic technology crucial to a nation's security is likely to raise concern (Li et al., 2017; Enderwick, 2011). A perceived threat to national security, such as the foreign acquisition of a communications equipment or aerospace and aircraft firm, may cause the host country government to resort to protectionism and quash the deal (Zhang \& He, 2014).

\subsubsection{Host Country GDP Growth}

The host country's GDP growth affects the role that protectionism plays in the cross-border acquisition completion and duration because it is indicative of the host country's economic condition (Erel et al., 2012; Zhou, Lan \& Tang, 2016; Lim \& Lee, 2017). The economic condition of the host country is likely to influence the extent to which a host government must set aside or restrain from engaging in protectionist behaviour for the sake of their economy (Zhou, Lan \& Tang, 2016; Erel et al., 2012). According to Erel, Liao and Weisbach (2012), firms from weaker economies tend to be easier to acquire because 
foreign investment is desirable in the context of economic downturn. I capture economic condition using the real growth rate of GDP in the host country, in the year of the focal deal announcement. I obtained these values from World Bank.

\subsubsection{Control Variables}

Following the existing literature, controls at deal, firm and country levels are incorporated into my model to account for those factors that may confound the effect of protectionism on cross-border acquisition completion and duration. The controls include, percentage sought, attitude of the transaction, and same industry acquisition at the deal level and Fortune 500 rank and economic importance at the firm level. Finally, this study controls for the host country's unemployment rate, cultural distance at the country level.

\subsubsection{Percentage Sought}

I controlled for the percentage of shares that the acquirer sought in the cross-border acquisition transaction. A high ownership stake transaction is intrinsically "more sensitive to interest groups" (Zhang \& He, 2014, p. 219) and therefore, could reduce the likelihood of completion and extend the transaction's duration (e.g., by affecting acquisition approval procedures) (Muehlfeld, Sahib \& van Witteloostuijn, 2007; Dikova et al., 2010). The percentage sought was sourced from SDC.

\subsubsection{Attitude of the Transaction}

The attitude of the target's management of the cross-border acquisition was factored into the model. Each deal was assigned an attitude (as provided by the SDC database): friendly if the board recommended the offer, hostile if the board officially rejected the offer but the acquirer persisted with the takeover, neutral if the target's management was not involved, not applicable if the attitude of the board was irrelevant and finally, unsolicited if the offer was not previously communicated to the board and they had yet to endorse or resist the offer. To prepare this data for analysis a dichotomous variable was constructed. An acquisition was coded as 1 if hostile and 0 for otherwise.

\subsubsection{Same Industry Acquisition}


Acquirers from the same industry as the target firm are more likely to experience a successful result following their acquisition attempt (Li et al., 2017; Muehlfeld et al., 2007). Where the acquirer and target firms are in the same industry at the 2-digit Standard Industrial Classification [SIC] level, the deal is coded as 1 and 0 if otherwise.

\subsubsection{Target Firm Fortune 500 Rank}

Should a firm be given a Fortune 500 rank, it can be used as an indicator of a firm's significance to the U.S. economy. The Fortune 500 lists the top 500 firms in the U.S. by total revenue (Fortune, 2017). Highly ranked firms are likely to be perceived as desirable firms by both prospective acquirers and the host governments. Hence, a conflict of interest between these two stakeholders may render a foreign acquirer's pursuit of such firms difficult, should they even get to the announcement stage of the cross-border acquisition process (Dinc \& Erel, 2013).

\subsubsection{Economic Importance}

In a similar fashion to a target firm's Fortune 500 rank, I expect the economic importance of the target firm to influence the relationship between protectionism and cross-border acquisition completion likelihood and duration. Accordingly, a variable capturing the target's economic importance to the host country economy is utilised in this study as a control. It is measured as the ratio of target firm employment to total labor force of the host country, following Bertrand et al. (2016). As one would expect, the greater the number of employees employed by a firm within an economy, the more important that firm is to that economy. An economically important target firm is more likely to incite protectionism (towards an announced cross-border acquisition) than a target firm that is insignificant within the domestic economy. The employee number of the target firm in the year prior to the deal was obtained from Compustat as part of the firm-level data collection. The total labour force of the host country was sourced online from World Bank (Bertrand et al., 2016).

\subsubsection{Unemployment Rate}

The host country unemployment rate in the year of the focal acquisition's announcement is an important control variable influencing the likelihood of completion and the duration. 
The dominant view holds that cross-border acquisitions eliminate jobs (Oldford \& Otchere, 2016). In the case of high unemployment, demonstrations of protectionism may be used to appeal to voters who are frustrated with the employment situation (Rowoldt \& Starke, 2016). The unemployment rate of the host country was sourced online from World Bank.

\subsubsection{Cultural Distance}

I include the cultural distance between the home and host countries as a control variable, using Kogut and Singh's (1988) index based on Hofstede's (1980) cultural dimension data (specifically, the power distance, uncertainty avoidance, masculinity/femininity and individualism/collectivism dimensions). Kogut and Singh's index (1988) is customarily used by researchers who study cultural differences (e.g., Dikova et al., 2010; Popli et al., 2016; Popli \& Kumar, 2016). Cultural similarity has been found to induce a higher degree of perceived trust between parties, reducing the potential for conflict and hence, the potential for protectionism to negatively affect the outcomes of a cross-border acquisition attempt (Gartzke \& Gleditsch, 2006; Kogut \& Singh, 1988; Bertrand et al., 2016). This is keeping with the ideas expressed by Dikova et al. (2010) who suggest that cultural differences contribute to standstills during acquisition deals and therefore, to a longer duration and even to abandonment.

\subsubsection{Country dummy}

Country dummy is coded as a dichotomous variable that takes the value of 1 , if the host country was the U.S. and 0 if it was Canada.

Furthermore, I included year dummies to control for the time effect and acknowledge any annual changes over the course of the sample period.

\subsection{Analytical Method}

The statistical software STATA was used to conduct data analyses. Two different methods were adopted in this study to analyse the two distinct dependent variables: completion likelihood and duration. Firstly, logistic regression was employed to test completion because the dependent variable is dichotomous in nature (i.e. 1 or 0 ). A logistic regression model estimates the probability of an event occurring (the dependent variable i.e. the 
probability that an announced acquisition is completed) for a given value for X (Ang, 2014; Kleinbaum \& Klein, 2009). The S-shaped response curve of the logistic function is particularly appropriate for this research. The S-shape indicates that the effect of host country protectionism on the risk of acquisition completion is minimal until some threshold of protectionism is reached (Kleinbaum \& Klein, 2009). In this study I argue that legitimacy concerns are the mechanism through which this threshold of protectionism is reached, at which point the likelihood of completion tapers off dramatically.

Second, a Poisson regression model is used for duration given that it is a count-type variable. Count-dependent variables do not follow normal distribution. As such, they cannot be addressed by a multiple linear regression model. Using a multiple linear regression model to analyse relationships involving count-dependent variables can lead to inefficient and biased regression coefficients (Ang, 2014; Coxe, West \& Aiken, 2009). "The probability of an occurrence using a Poisson regression model is determined by a Poisson distribution, where the mean of the distribution is a function of the independent variables" (Ang, 2014, p. 259). In the robustness section, I used OLS regression to test the variable, following Dikova et al. (2010) and Li et al. (2017). 


\section{CHAPTER 5 RESULTS}

This chapter reports the descriptive statistics and the correlation matrix. This is followed by the results of hypotheses testing.

\subsection{Descriptive Statistics and Correlation Matrix}

\subsubsection{Descriptive Statistics}

Of the 675 cross-border acquisitions, 584 were completed and 91 were withdrawn. Table

4.1, Table 4.1.1 and Table 4.1.2 present the descriptive statistics of the final samples of 675 (completion) and 548 (duration) observations. Table 4.1 shows that, of the 675 cross-border acquisitions, 17 percent (115) took place in Canada and 83 percent (560) took place in the U.S. Furthermore, during the course of the 20-year sample period 1671 protectionist actions were taken by the U.S. and 312 were taken by Canada.

Table 4.1 Descriptive Statistics of Sample: Number of Cross-border Acquisitions Completed/Withdrawn and Protectionist Actions

\begin{tabular}{|l|l|l|l|}
\hline Host Country & Canada & USA & Total \\
\hline \# Completed (percentage) & $97(84 \%)$ & $487(87 \%)$ & $584(86.5 \%)$ \\
\hline \# Withdrawn (percentage) & $18(16 \%)$ & $73(13 \%)$ & $91(13.5 \%)$ \\
\hline \# Total (percentage) & $115(17 \%)$ & $560(83 \%)$ & $675(100 \%)$ \\
\hline \# Protectionist Actions (percentage) & $312(16 \%)$ & $1671(84 \%)$ & $1983(100 \%)$ \\
\hline
\end{tabular}

Table 4.1.1 shows the number of completed cross-border acquisitions alongside the number of protectionist actions, per year, in each host country. 
Table 4.1.1 Descriptive Statistics of Cross-border Acquisition Completion: Number of Acquisitions

Completed and Protectionist Actions

\begin{tabular}{|c|c|c|c|c|c|c|}
\hline \multirow[b]{2}{*}{ Year } & \multicolumn{3}{|l|}{ Canada } & \multicolumn{3}{|l|}{ USA } \\
\hline & $\begin{array}{l}\text { Completed } \\
\text { Acquisitions }\end{array}$ & $\begin{array}{l}\text { Total } \\
\text { Acquisition } \\
\text { Attempts }\end{array}$ & $\begin{array}{l}\text { Protectionist } \\
\text { Actions }\end{array}$ & $\begin{array}{l}\text { Completed } \\
\text { Acquisitions }\end{array}$ & $\begin{array}{l}\text { Total } \\
\text { Acquisition } \\
\text { Attempts }\end{array}$ & $\begin{array}{l}\text { Protectionist } \\
\text { Actions }\end{array}$ \\
\hline 1995 & $3(75)$ & 4 & 42 & $14(78)$ & 18 & 94 \\
\hline 1996 & $0(0)$ & 2 & 3 & $15(79)$ & 19 & 65 \\
\hline 1997 & $6(86)$ & 7 & 39 & $27(93)$ & 29 & 84 \\
\hline 1998 & $4(100)$ & 4 & 32 & $36(90)$ & 40 & 102 \\
\hline 1999 & $5(44)$ & 9 & 17 & $63(95)$ & 66 & 63 \\
\hline 2000 & $6(100)$ & 6 & 13 & $57(90)$ & 63 & 13 \\
\hline 2001 & $8(100)$ & 8 & 25 & $20(83)$ & 24 & 126 \\
\hline 2002 & $4(100)$ & 4 & 6 & $20(90)$ & 22 & 90 \\
\hline 2003 & $7(88)$ & 8 & 16 & $17(81)$ & 21 & 107 \\
\hline 2004 & $4(100)$ & 6 & 15 & $16(89)$ & 18 & 111 \\
\hline 2005 & $4(100)$ & 4 & 4 & $20(91)$ & 22 & 77 \\
\hline 2006 & $6(86)$ & 7 & 9 & $23(82)$ & 28 & 82 \\
\hline 2007 & $9(90)$ & 10 & 2 & 34 (97) & 35 & 94 \\
\hline 2008 & $9(100)$ & 9 & 6 & $23(85)$ & 27 & 75 \\
\hline 2009 & $5(83)$ & 6 & 7 & $13(81)$ & 16 & 93 \\
\hline 2010 & $3(100)$ & 3 & 3 & $18(90)$ & 20 & 53 \\
\hline 2011 & $3(60)$ & 5 & 4 & $7(78)$ & 9 & 81 \\
\hline 2012 & $1(100)$ & 1 & 17 & $19(90)$ & 21 & 84 \\
\hline 2013 & $3(75)$ & 4 & 21 & $8(73)$ & 11 & 58 \\
\hline 2014 & $5(100)$ & 5 & 25 & $14(70)$ & 20 & 54 \\
\hline 2015 & $3(100)$ & 3 & 6 & $27(77)$ & 35 & 65 \\
\hline
\end{tabular}

Note: Percentages in brackets 
Table 4.1.2 shows the minimum and maximum cross-border acquisition durations, alongside the number of protectionist actions, per year, in each host country.

Table 4.1.2 Descriptive Statistics of Cross-border Acquisition Duration: Acquisition Duration in Days and Number of Protectionist Actions

\begin{tabular}{|c|c|c|c|c|c|c|c|c|}
\hline \multirow{2}{*}{ Year } & \multicolumn{4}{|c|}{ Canada } & \multicolumn{4}{|l|}{ USA } \\
\hline & Min & Max & Average & Protectionist Actions & Min & Max & Average & Protectionist Actions \\
\hline 1995 & 75 & 140 & 115 & 42 & 0 & 187 & 76 & 94 \\
\hline 1996 & $\mathrm{~N} / \mathrm{A}$ & N/A & N/A & 3 & 0 & 189 & 124 & 65 \\
\hline 1997 & 36 & 336 & 134 & 39 & 33 & 212 & 96 & 84 \\
\hline 1998 & 33 & 116 & 73 & 32 & 35 & 464 & 116 & 102 \\
\hline 1999 & 37 & 221 & 102 & 17 & 0 & 373 & 94 & 63 \\
\hline 2000 & 48 & 331 & 152 & 13 & 0 & 513 & 128 & 13 \\
\hline 2001 & 62 & 175 & 113 & 25 & 43 & 480 & 137 & 126 \\
\hline 2002 & 59 & 142 & 95 & 6 & 0 & 259 & 101 & 90 \\
\hline 2003 & 82 & 122 & 97 & 16 & 36 & 362 & 135 & 107 \\
\hline 2004 & 42 & 80 & 64 & 15 & 10 & 267 & 136 & 111 \\
\hline 2005 & 37 & 135 & 86 & 4 & 42 & 331 & 109 & 77 \\
\hline 2006 & 69 & 116 & 86 & 9 & 36 & 543 & 129 & 82 \\
\hline 2007 & 50 & 273 & 111 & 2 & 37 & 450 & 102 & 94 \\
\hline 2008 & 49 & 238 & 81 & 6 & 38 & 163 & 88 & 75 \\
\hline 2009 & 55 & 162 & 81 & 7 & 50 & 1329 & 191 & 93 \\
\hline 2010 & 50 & 54 & 35 & 3 & 0 & 360 & 126 & 53 \\
\hline 2011 & 61 & 172 & 110 & 4 & 47 & 441 & 158 & 81 \\
\hline 2012 & 57 & 57 & 57 & 17 & 32 & 286 & 120 & 84 \\
\hline 2013 & 51 & 115 & 78 & 21 & 36 & 247 & 98 & 58 \\
\hline 2014 & 60 & 190 & 96 & 25 & 0 & 442 & 136 & 54 \\
\hline 2015 & 72 & 242 & 135 & 6 & 32 & 401 & 133 & 65 \\
\hline
\end{tabular}

\subsubsection{Correlation Matrix}

The means, standard deviations and correlation matrices for the variables used in this study are presented in Table 4.2. There are no instances of high correlation (i.e. an absolute value of 0.7 or above) between the explanatory variables used in this study (Spencer, 1995). Moreover, a variance inflation factor (VIF) test was conducted. The average VIF for the model is 1.26 and the highest value is 1.79 , well below the threshold level of 10, indicating that multicollinearity is not of concern in this regression analysis. 
Table 4.2 Summary Statistics and Correlation Matrix $(n=675)$

\begin{tabular}{|c|c|c|c|c|c|c|c|c|c|c|c|c|c|c|c|c|c|}
\hline & Variable & Mean & s.d. & (1) & (2) & (3) & (4) & $(5)$ & (6) & (7) & (8) & (9) & (10) & $(11)$ & (12) & (13) & (14) \\
\hline (1) & Completion & 0.85 & 0.35 & 1.00 & & & & & & & & & & & & & \\
\hline (2) & Duration & 106.56 & 93.27 & . & 1.00 & & & & & & & & & & & & \\
\hline (3) & Protectionist Actions & 28.35 & 20.53 & -0.02 & 0.02 & 1.00 & & & & & & & & & & & \\
\hline (4) & Target Size & 2.31 & 0.85 & -0.07 & 0.34 & 0.04 & 1.00 & & & & & & & & & & \\
\hline (5) & Target Fortune 500 Rank & 0.04 & 0.19 & -0.12 & 0.15 & 0.03 & 0.25 & 1.00 & & & & & & & & & \\
\hline (6) & Target Economic Importance & 0.00 & 0.02 & -0.10 & 0.06 & -0.12 & 0.33 & 0.10 & 1.00 & & & & & & & & \\
\hline (7) & Target Performance & -17.28 & 114.04 & -0.06 & 0.05 & -0.06 & 0.33 & 0.02 & 0.05 & 1.00 & & & & & & & \\
\hline (8) & Target National Security Concern & 0.07 & 0.25 & -0.05 & 0.14 & 0.02 & 0.07 & -0.01 & 0.02 & -0.02 & 1.00 & & & & & & \\
\hline (9) & Ownership Stake Sought & 97.07 & 10.19 & -0.03 & 0.02 & 0.02 & 0.06 & 0.05 & 0.01 & 0.06 & -0.10 & 1.00 & & & & & \\
\hline (10) & Hostile Deal & 0.03 & 0.16 & -0.19 & 0.06 & -0.01 & 0.13 & 0.03 & 0.18 & 0.03 & -0.02 & 0.01 & 1.00 & & & & \\
\hline (11) & Same Industry Acquisition & 0.59 & 0.49 & -0.05 & 0.06 & 0.07 & 0.11 & 0.11 & 0.02 & -0.01 & -0.09 & 0.05 & 0.07 & 1.00 & & & \\
\hline (12) & Host Country Unemployment Rate & 6.00 & 1.69 & -0.07 & 0.03 & -0.15 & -0.07 & -0.02 & 0.09 & -0.11 & -0.03 & 0.03 & 0.06 & 0.04 & 1.00 & & \\
\hline (13) & Host Country GDP Growth & 2.77 & 1.73 & 0.03 & -0.03 & -0.14 & -0.03 & -0.01 & 0.04 & 0.13 & 0.07 & -0.08 & 0.01 & -0.11 & -0.41 & 1.00 & \\
\hline (14) & Cultural Distance & 0.76 & 1.00 & 0.04 & -0.04 & 0.03 & 0.14 & 0.03 & -0.02 & 0.02 & -0.03 & -0.11 & -0.04 & 0.03 & -0.09 & -0.07 & 1.00 \\
\hline (15) & Country Dummy & 0.76 & 0.43 & 0.02 & 0.06 & 0.41 & 0.17 & 0.09 & -0.23 & 0.00 & 0.04 & -0.01 & -0.04 & 0.04 & -0.50 & -0.03 & 0.25 \\
\hline
\end{tabular}




\subsection{Hypotheses and other Results}

\subsubsection{Cross-border Acquisition Completion}

Table 4.3 shows the results from the logistic regression model, used to test the hypotheses on the likelihood of acquisition completion. Model 1 is the baseline model that includes only the control variables. Model 2 introduces the independent variable protectionist actions to test Hypothesis 1a. Model 3 adds the interaction term of target size to test Hypothesis 2a. Model 4 adds the interaction term of target performance to test Hypothesis 3a. Model 5 adds the interaction term of target national security concern to test Hypothesis 4a. Model 6 adds the interaction term of host country GDP growth to test Hypothesis 5a.

Hypothesis 1a states that the higher the degree of protectionism in the host country, the lower the likelihood of completion for the cross-border acquisition. The coefficient of Protectionist Actions is negative and significant (Model 2: $\mathrm{b}=-0.22, \mathrm{p}<0.1$ ), indicating a negative relationship between protectionism and the likelihood of acquisition completion. Therefore, Hypothesis 1a is supported. 
Table 4.3 Logistic Regression Model Cross-border Acquisition Completion Results

\begin{tabular}{|c|c|c|c|c|c|c|c|}
\hline DV: Completion (0/1) & $\begin{array}{l}\text { (1) } \\
\text { Controls } \\
\text { Only }\end{array}$ & $\begin{array}{l}\text { (2) } \\
\text { Protectionist } \\
\text { Actions }\end{array}$ & $\begin{array}{l}\text { (3) } \\
\text { Target } \\
\text { Size }\end{array}$ & $\begin{array}{l}\text { (4) } \\
\text { Target } \\
\text { Performance }\end{array}$ & $\begin{array}{l}(5) \\
\text { Target National Security } \\
\text { Concern }\end{array}$ & $\begin{array}{l}\text { (6) } \\
\text { Host Country GDP } \\
\text { Growth }\end{array}$ & $\begin{array}{l}\text { (7) } \\
\text { Full } \\
\text { Model }\end{array}$ \\
\hline \multirow[t]{2}{*}{ Target Size } & 0.09 & 0.09 & 0.17 & 0.09 & 0.08 & 0.09 & 0.16 \\
\hline & $(0.17)$ & $(0.17)$ & $(0.17)$ & $(0.18)$ & $(0.17)$ & $(0.17)$ & $(0.18)$ \\
\hline \multirow[t]{2}{*}{ Target Fortune 500 Rank } & $-1.17^{*}$ & $-1.12 *$ & $-1.02 *$ & $-1.09 *$ & $-1.18^{*}$ & $-1.13 *$ & $-1.08^{*}$ \\
\hline & $(0.59)$ & $(0.59)$ & $(0.61)$ & $(0.59)$ & $(0.59)$ & $(0.59)$ & $(0.61)$ \\
\hline \multirow[t]{2}{*}{ Target Economic Importance } & -6.23 & -6.34 & $-10.94 *$ & -6.84 & -6.06 & -6.27 & $-10.66^{*}$ \\
\hline & $(6.14)$ & $(5.73)$ & $(5.77)$ & $(5.83)$ & $(5.77)$ & $(5.67)$ & $(5.77)$ \\
\hline \multirow[t]{2}{*}{ Target Performance } & $-0.01 *$ & $-0.01 *$ & $-0.01 *$ & $0.03+$ & $-0.01^{*}$ & $-0.01 *$ & $0.03+$ \\
\hline & $(0.00)$ & $(0.00)$ & $(0.00)$ & $(0.02)$ & $(0.00)$ & $(0.00)$ & $(0.02)$ \\
\hline \multirow[t]{2}{*}{ Target National Security Concern } & $-0.58+$ & $-0.58+$ & $-0.62+$ & $-0.61+$ & 2.29 & $-0.57+$ & 2.36 \\
\hline & $(0.43)$ & $(0.43)$ & $(0.43)$ & $(0.43)$ & $(2.32)$ & $(0.43)$ & $(2.33)$ \\
\hline \multirow[t]{2}{*}{ Ownership Stake Sought } & -0.01 & -0.01 & -0.01 & -0.01 & -0.01 & -0.01 & -0.01 \\
\hline & $(0.02)$ & $(0.02)$ & $(0.02)$ & $(0.02)$ & $(0.02)$ & $(0.02)$ & $(0.02)$ \\
\hline \multirow[t]{2}{*}{ Hostile Deal } & $-1.94 * * *$ & $-1.90 * * *$ & $-1.95 * * *$ & $-1.93 * * *$ & $-1.90 * * *$ & $-1.90 * * *$ & $-1.98 * * *$ \\
\hline & $(0.47)$ & $(0.47)$ & $(0.48)$ & $(0.47)$ & $(0.47)$ & $(0.47)$ & $(0.48)$ \\
\hline \multirow[t]{2}{*}{ Same Industry Acquisition } & -0.06 & -0.04 & -0.04 & -0.05 & -0.03 & -0.05 & -0.03 \\
\hline & $(0.26)$ & $(0.26)$ & $(0.26)$ & $(0.26)$ & $(0.26)$ & $(0.26)$ & $(0.26)$ \\
\hline \multirow[t]{2}{*}{ Host Country Unemployment Rate } & $-0.16^{*}$ & $-0.16^{*}$ & $-0.16^{*}$ & $-0.16^{*}$ & $-0.17 *$ & $-0.16^{*}$ & $-0.16^{*}$ \\
\hline & $(0.09)$ & $(0.09)$ & $(0.09)$ & $(0.09)$ & $(0.09)$ & $(0.09)$ & $(0.09)$ \\
\hline \multirow[t]{2}{*}{ Host Country GDP Growth } & 0.03 & 0.01 & 0.01 & 0.00 & 0.01 & 0.01 & -0.01 \\
\hline & $(0.08)$ & $(0.08)$ & $(0.08)$ & $(0.08)$ & $(0.08)$ & $(0.08)$ & $(0.08)$ \\
\hline Cultural Distance & 0.03 & 0.01 & 0.03 & 0.03 & 0.01 & 0.01 & 0.04 \\
\hline
\end{tabular}




\begin{tabular}{|c|c|c|c|c|c|c|c|}
\hline DV: Completion (0/1) & $\begin{array}{l}\text { (1) } \\
\text { Controls } \\
\text { Only }\end{array}$ & $\begin{array}{l}\text { (2) } \\
\text { Protectionist } \\
\text { Actions }\end{array}$ & $\begin{array}{l}\text { (3) } \\
\text { Target } \\
\text { Size }\end{array}$ & $\begin{array}{l}\text { (4) } \\
\text { Target } \\
\text { Performance }\end{array}$ & $\begin{array}{l}\text { (5) } \\
\text { Target National Security } \\
\text { Concern }\end{array}$ & $\begin{array}{l}(6) \\
\text { Host Country GDP } \\
\text { Growth }\end{array}$ & $\begin{array}{l}\text { (7) } \\
\text { Full } \\
\text { Model }\end{array}$ \\
\hline & $(0.12)$ & $(0.13)$ & $(0.13)$ & $(0.13)$ & $(0.13)$ & $(0.13)$ & $(0.13)$ \\
\hline \multirow[t]{2}{*}{ Country Dummy } & -0.21 & -0.04 & -0.20 & 0.03 & -0.05 & 0.01 & -0.08 \\
\hline & $(0.37)$ & $(0.40)$ & $(0.41)$ & $(0.40)$ & $(0.40)$ & $(0.41)$ & $(0.42)$ \\
\hline \multirow[t]{2}{*}{ Protectionist Actions } & & $-0.22+$ & -0.18 & $-0.22+$ & -0.16 & -0.20 & -0.09 \\
\hline & & $(0.17)$ & $(0.17)$ & $(0.17)$ & $(0.17)$ & $(0.17)$ & $(0.18)$ \\
\hline \multirow[t]{2}{*}{ Protectionist Actions x Target Size } & & & $-0.27 *$ & & & & $-0.26^{*}$ \\
\hline & & & $(0.13)$ & & & & $(0.13)$ \\
\hline \multirow[t]{2}{*}{ Protectionist Actions x Target Performance } & & & & $-0.87+$ & & & $-0.84+$ \\
\hline & & & & $(0.56)$ & & & $(0.55)$ \\
\hline \multirow[t]{2}{*}{$\begin{array}{l}\text { Protectionist Actions x Target National } \\
\text { Security Concern }\end{array}$} & & & & & $-0.89+$ & & $-0.93+$ \\
\hline & & & & & $(0.68)$ & & $(0.68)$ \\
\hline \multirow[t]{2}{*}{$\begin{array}{l}\text { Protectionist Actions x Host Country GDP } \\
\text { Growth }\end{array}$} & & & & & & 0.08 & 0.11 \\
\hline & & & & & & $(0.18)$ & $(0.18)$ \\
\hline Log likelihood & -247.4 & -246.5 & -244.4 & -245.4 & -245.6 & -246.4 & -242.3 \\
\hline LR Chi-square & $39.02 * * *$ & $40.82 * * *$ & $44.94 * * *$ & $43.09 * * *$ & $42.72 * * *$ & $41.01 * * *$ & $49.27 * * *$ \\
\hline Number of observations & 675 & 675 & 675 & 675 & 675 & 675 & 675 \\
\hline
\end{tabular}

Table 4.3 Logistic Regression Model Cross-border Acquisition Completion Results (cont'd) 
Hypothesis $2 \mathrm{a}$ predicts that the negative effect of protectionism on acquisition completion is stronger for large target firms. In Model 3, the coefficient of Protectionist Actions * Target Size has a significant and negative coefficient $(b=-0.27, p<0.05)$, suggesting that an acquisition's completion likelihood is moderated by the target firm's size. Furthermore, the coefficient of Protectionist Actions remains negative but, not significant after the inclusion of the interaction term, providing support for Hypothesis 2a.

Hypothesis 3 a states that the negative effect of protectionism on acquisition completion is stronger for high-performing target firms. In Model 3, the interaction term of Protectionist Actions * Target Performance has a significant and negative coefficient $(b=-0.87, p<0.1)$, suggesting that an acquisition's completion likelihood is moderated by the target firm's performance, providing support for Hypothesis $3 \mathrm{a}$.

Hypothesis $4 \mathrm{a}$ predicts that the negative effect of protectionism on acquisition completion is stronger for target firms in an industry with national security concerns. In Model 4, the interaction term Protectionist Actions * Target National Security Concern has a significant and negative coefficient $(b=-0.89, p<0.1)$. This suggests that acquisition completion likelihood is moderated by the target firm's significance to (the host country's) national security. Furthermore, the coefficient of Protectionist Actions continues to have a significant negative direct impact on acquisition duration with the inclusion of the interaction term, providing support for Hypothesis 4a.

Hypothesis 5a states that the negative effect of protectionism on acquisition completion is stronger when the host country has experienced high GDP growth in the year of the focal deal. In Model 5, the interaction of protectionist actions and host country GDP growth is positive and failed to reach statistical significance $(b=0.08, p=n . s$. $)$ thus, Hypothesis $5 a$ is not supported.

Turning to control variables, the effects of a number of controls in Model 1 of Table 4.3 are noteworthy. Although, several were not significant (target economic importance, ownership stake sought, same industry acquisition, cultural distance, country dummy, target size and host country GDP growth). All significant control effects were in line with expectations. 
Target Fortune 500 rank is negatively related to cross-border acquisition completion. The Fortune 500 lists the top 500 firms in the U.S. by total revenue (Fortune, 2017). Ranked firms are less likely to be successfully acquired. Because of their significance to the local economy, host country governments may prefer that these firms belong to the domestic economy and block foreign interest. Hostile deal is negatively related to cross-border acquisition completion likelihood. This result is not surprising given that hostile bids occur when there is misalignment between the interests of the target firm's management and its shareholders (Rowoldt \& Starke, 2016). If target management opposes a deal which shareholders support (or vice versa), completion may be obstructed by the inner workings of the target. Furthermore, as expected, target firm performance is negatively related to the likelihood of cross-border acquisition completion. For much of the same reasons as a Fortune 500 firm rank, cross-border acquisitions are more likely to be incomplete if the target involved is a high performer. Finally, target national security concern is negatively related to cross-border acquisition completion likelihood. So, too, is the host country unemployment rate.

\subsubsection{Cross-border Acquisition Duration}

Table 4.4 shows the results from the Poisson regression model to test hypotheses on acquisition duration. Model 1 is the baseline model that includes only the control variables. Model 2 introduces the independent variable protectionist actions. Model 3 adds the interaction term of target size to test Hypothesis $2 \mathrm{~b}$. Model 4 adds the interaction term of target performance to test Hypothesis $3 \mathrm{~b}$. Model 5 adds the interaction term of target national security concern to test Hypothesis 4b. Model 6 adds the interaction term of host country GDP growth to test Hypothesis $5 b$.

The inverse mills ratio was used to control for any potential sample selection bias arising from examining only completed cross-border acquisitions. I calculated the inverse mills' ratio based on my regression for acquisition completion and included it for the acquisition duration model (Dikova et al., 2010; Li et al., 2017).

Hypothesis $1 \mathrm{~b}$ states the higher the degree of protectionism in the host country, the longer the time lapse between the announcement and effective dates of the acquisition. The 
coefficient of Protectionist Actions is positive and significant $(b=0.02, p<0.001)$, indicating a positive relationship between protectionist actions and acquisition duration. The added contribution from Model 1 to Model 2 is significant $(\mathrm{p}<0.001)$, suggesting that the inclusion of protectionist actions contributes significantly to explaining acquisition duration. Therefore, Hypothesis $1 \mathrm{~b}$ is supported. 
Table 4.4 Poisson Regression Model Cross-border Acquisition Duration Results

\begin{tabular}{|c|c|c|c|c|c|c|c|}
\hline DV: Duration & $\begin{array}{l}\text { (1) } \\
\text { Controls } \\
\text { Only }\end{array}$ & $\begin{array}{l}\text { (2) } \\
\text { Protectionist } \\
\text { Actions }\end{array}$ & $\begin{array}{l}\text { (3) } \\
\text { Target } \\
\text { Size }\end{array}$ & $\begin{array}{l}\text { (4) } \\
\text { Target } \\
\text { Performance }\end{array}$ & $\begin{array}{l}\text { (5) } \\
\text { Target National } \\
\text { Security Concern }\end{array}$ & $\begin{array}{l}\text { (6) } \\
\text { Host Country GDP } \\
\text { Growth }\end{array}$ & $\begin{array}{l}\text { (7) } \\
\text { Full } \\
\text { Model }\end{array}$ \\
\hline \multirow[t]{2}{*}{ Target Size } & $0.43 * * *$ & $0.43^{* * *}$ & $0.43^{* * *}$ & $0.43^{* * *}$ & $0.43^{* * *}$ & $0.42 * * *$ & $0.42^{* * *}$ \\
\hline & $(0.01)$ & $(0.01)$ & $(0.01)$ & $(0.01)$ & $(0.01)$ & $(0.01)$ & $(0.01)$ \\
\hline \multirow[t]{2}{*}{ Target Fortune 500 Rank } & $0.20^{* * *}$ & $0.24 * * *$ & $0.25^{* * *}$ & $0.23^{* * *}$ & $0.25^{* * *}$ & $0.27 * * *$ & $0.29 * * *$ \\
\hline & $(0.04)$ & $(0.05)$ & $(0.05)$ & $(0.05)$ & $(0.05)$ & $(0.05)$ & $(0.05)$ \\
\hline \multirow[t]{2}{*}{ Target Economic Importance } & $-10.51 * * *$ & $-10.18^{* * *}$ & $-9.99 * * *$ & $-10.04 * * *$ & $-10.24 * * *$ & $-9.32 * * *$ & $-9.00 * * *$ \\
\hline & $(0.53)$ & $(0.54)$ & $(0.54)$ & $(0.54)$ & $(0.54)$ & $(0.54)$ & $(0.54)$ \\
\hline \multirow[t]{2}{*}{ Target Performance } & $-0.00^{* * *}$ & $-0.00^{* * *}$ & $-0.00^{* * *}$ & $-0.00^{* * *}$ & $-0.00^{* * *}$ & $-0.00^{* * *}$ & $-0.00^{* * *}$ \\
\hline & $(0.00)$ & $(0.00)$ & $(0.00)$ & $(0.00)$ & $(0.00)$ & $(0.00)$ & $(0.00)$ \\
\hline \multirow{2}{*}{ Target National Security Concern } & $0.38^{* * *}$ & $0.39 * * *$ & $0.39 * * *$ & $0.39^{* * *}$ & 0.02 & $0.39 * * *$ & \begin{tabular}{|l|}
-0.08 \\
\end{tabular} \\
\hline & $(0.02)$ & $(0.02)$ & $(0.02)$ & $(0.02)$ & $(0.07)$ & $(0.02)$ & $(0.07)$ \\
\hline \multirow[t]{2}{*}{ Ownership Stake Sought } & $-0.00 *$ & $-0.00 *$ & $-0.00 *$ & $-0.00^{*}$ & $-0.00^{*}$ & -0.00 & -0.00 \\
\hline & $(0.00)$ & $(0.00)$ & $(0.00)$ & $(0.00)$ & $(0.00)$ & $(0.00)$ & $(0.00)$ \\
\hline \multirow[t]{2}{*}{ Hostile Deal } & $-0.38^{* * *}$ & $-0.30^{* * *}$ & $-0.29 * * *$ & $-0.30^{* * *}$ & $-0.32 * * *$ & $-0.28^{* * *}$ & $-0.27^{* * *}$ \\
\hline & $(0.08)$ & $(0.08)$ & $(0.08)$ & $(0.08)$ & $(0.08)$ & $(0.08)$ & $(0.08)$ \\
\hline \multirow[t]{2}{*}{ Same Industry Acquisition } & $0.05^{* * *}$ & $0.05^{* * *}$ & $0.05^{* * *}$ & $0.05^{* * *}$ & $0.05^{* * *}$ & $0.06^{* * *}$ & $0.06^{* * *}$ \\
\hline & $(0.01)$ & $(0.01)$ & $(0.01)$ & $(0.01)$ & $(0.01)$ & $(0.01)$ & $(0.01)$ \\
\hline \multirow[t]{2}{*}{ Host Country Unemployment Rate } & $0.02 * * *$ & $0.02 * * *$ & $0.02 * * *$ & $0.02 * * *$ & $0.02 * * *$ & $0.02 * * *$ & $0.02 * * *$ \\
\hline & $(0.00)$ & $(0.00)$ & $(0.00)$ & $(0.00)$ & $(0.00)$ & $(0.00)$ & $(0.00)$ \\
\hline \multirow[t]{2}{*}{ Host Country GDP Growth } & $-0.01^{* * *}$ & $-0.01 * * *$ & $-0.01 * *$ & $-0.01 * *$ & $-0.01 * * *$ & -0.00 & 0.00 \\
\hline & $(0.00)$ & $(0.00)$ & $(0.00)$ & $(0.00)$ & $(0.00)$ & $(0.00)$ & $(0.00)$ \\
\hline \multirow[t]{2}{*}{ Cultural Distance } & $-0.08^{* * *}$ & $-0.08^{* * *}$ & $-0.08^{* * *}$ & $-0.08^{* * *}$ & $-0.08^{* * *}$ & $-0.08^{* * *}$ & $-0.08 * * *$ \\
\hline & $(0.00)$ & $(0.00)$ & $(0.00)$ & $(0.00)$ & $(0.00)$ & $(0.00)$ & $(0.00)$ \\
\hline \multirow[t]{2}{*}{ Inverse Mills Ratio } & $0.48^{* * *}$ & $0.38^{* * *}$ & $0.37^{* * *}$ & $0.39 * * *$ & $0.40^{* * *}$ & $0.34 * * *$ & $0.35^{* * *}$ \\
\hline & $(0.09)$ & $(0.10)$ & $(0.10)$ & $(0.10)$ & $(0.10)$ & $(0.10)$ & $(0.10)$ \\
\hline
\end{tabular}




\begin{tabular}{|c|c|c|c|c|c|c|c|}
\hline DV: Duration & $\begin{array}{l}\text { (1) } \\
\text { Controls } \\
\text { Only }\end{array}$ & $\begin{array}{l}(2) \\
\text { Protectionist } \\
\text { Actions }\end{array}$ & $\begin{array}{l}(3) \\
\text { Target } \\
\text { Size }\end{array}$ & $\begin{array}{l}\text { (4) } \\
\text { Target } \\
\text { Performance }\end{array}$ & $\begin{array}{l}\text { (5) } \\
\text { Target National } \\
\text { Security Concern }\end{array}$ & $\begin{array}{l}\text { (6) } \\
\text { Host Country GDP } \\
\text { Growth }\end{array}$ & $\begin{array}{l}\text { (7) } \\
\text { Full } \\
\text { Model }\end{array}$ \\
\hline \multirow[t]{2}{*}{ Protectionist Actions } & & $0.02 * * *$ & $0.01 *$ & $0.02 * * *$ & $0.01 *$ & $0.00 *$ & $0.02 * * *$ \\
\hline & & $(0.01)$ & $(0.01)$ & $(0.01)$ & $(0.01)$ & $(0.01)$ & $(0.01)$ \\
\hline \multirow[t]{2}{*}{ Protectionist Actions x Target Size } & & & $0.04 * * *$ & & & & $0.04 * * *$ \\
\hline & & & $(0.00)$ & & & & $(0.00)$ \\
\hline \multirow[t]{2}{*}{$\begin{array}{l}\text { Protectionist Actions x Target } \\
\text { Performance }\end{array}$} & & & & $0.08 * * *$ & & & $0.08 * * *$ \\
\hline & & & & $(0.01)$ & & & $(0.01)$ \\
\hline \multirow[t]{2}{*}{$\begin{array}{l}\text { Protectionist Actions x Target National } \\
\text { Security Concern }\end{array}$} & & & & & $0.12 * * *$ & & $0.15^{* * *}$ \\
\hline & & & & & $(0.02)$ & & $(0.02)$ \\
\hline \multirow[t]{2}{*}{$\begin{array}{l}\text { Protectionist Actions x Host Country } \\
\text { GDP Growth }\end{array}$} & & & & & & $-0.09 * * *$ & $-0.09 * * *$ \\
\hline & & & & & & $(0.01)$ & $(0.01)$ \\
\hline Log likelihood & -14201 & -14195 & -14162 & -14174 & -14182 & -14105 & -14028 \\
\hline LR Chi-square & $8033 * * *$ & $8046^{* * *}$ & $8110^{* * *}$ & $8088 * * *$ & $8072 * * *$ & $8225 * * *$ & $8379 * * *$ \\
\hline Number of observations & 548 & 548 & 548 & 548 & 548 & 548 & 548 \\
\hline
\end{tabular}

Table 4.4 Poisson Regression Model Cross-border Acquisition Duration Results (cont'd) 
Hypothesis $2 \mathrm{~b}$ predicts that the positive effect of protectionism on acquisition duration is stronger for large target firms. In Model 3, the interaction of protectionist actions and target firm size has a significant and positive coefficient $(b=0.04, p<0.001)$, suggesting that an acquisition's duration is moderated by the target firm's size. Furthermore, the coefficient of Protectionist Actions continues to have a significant positive direct impact on acquisition duration with inclusion of the interaction term, providing support for Hypothesis $2 \mathrm{~b}$.

Hypothesis $3 \mathrm{~b}$ states that the positive effect of protectionism on acquisition duration is stronger for high-performing target firms. In Model 4, the interaction of protectionist actions and target firm performance has a significant and positive coefficient $(b=0.08$, $\mathrm{p}<0.001$ ), suggesting that an acquisition's duration is moderated by the performance of the target firm. Furthermore, the coefficient of Protectionist Actions remains positively significant after the inclusion of the interaction term, providing support for Hypothesis $3 \mathrm{~b}$.

Hypothesis $4 \mathrm{~b}$ predicts that the positive effect of protectionism on acquisition duration is stronger for target firms in an industry with national security concerns. In Model 5, the interaction of protectionist actions and national security concern has a significant and positive coefficient $(b=0.12, p<0.001)$, suggesting that an acquisition's duration is moderated by the target firm's significance to the national security (of the host country). Furthermore, the coefficient of Protectionist Actions continues to have a significant positive direct impact on acquisition duration with inclusion of the interaction term, providing support for Hypothesis 4b.

Hypothesis $5 \mathrm{~b}$ predicts that the positive effect of protectionism on acquisition duration is stronger when the host country has experienced high GDP growth in the year of the focal deal. In Model 6, the interaction of protectionist actions and host country GDP growth is negative and significant $(b=-0.09, p<0.001)$ thus, Hypothesis $5 b$ is not supported.

Turning to control variables, the effects of a number of controls in Model 1 of Table 4.4 are noteworthy. Target economic importance is negatively related to cross-border acquisition duration. Whilst this control was included under the assumption that the more significant a target firm is to a host country, the longer the duration of the deal due to institutional 
resistance. Economic importance is calculated as the proportion of the able workforce belonging to the target firm. A possible explanation for this relationship may be that acquisitions of target firms with large workforces are completed quickly, where the domestic firm would otherwise fail without the deal (Conybeare \& Kim, 2010).

In line with expectations, target Fortune 500 rank is positively related to cross-border acquisition duration. The firms which feature on this list are desirable entities and thus, may take longer to successfully acquire. Host country unemployment rate is positively related to cross-border acquisition duration. As expected, target size is positively related to crossborder acquisition duration, as was target national security concern. These kinds of acquisitions are more likely to be susceptible to the adverse judgements of host country institutions which extend the acquisition process. 


\section{CHAPTER 6. DISCUSSION AND CONCLUSION}

\subsection{Discussion}

Cross-border acquisitions are a strategically attractive entry-mode because they facilitate quick access to new markets, resources and capabilities (Shimizu et al., 2004). The complexity associated with successfully completing these transactions has prompted a vast body of work scrutinising the various success factors of the entry-mode. This study engages the legitimacy perspective rooted in the institution-based view, to investigate the impact of protectionism, on cross-border acquisition completion likelihood and duration.

The first hypothesis, which tests the effect of protectionism on an announced cross-border acquisition's completion likelihood and duration, is supported. The second hypothesis, on the positive moderating effect of target firm size on the negative relationship between protectionism and completion, and the positive relationship between protectionism and duration, is supported. The third hypothesis, on the positive moderating effect of target firm performance on the negative relationship between protectionism and completion, and the positive relationship between protectionism and duration, is supported. The fourth hypothesis, on the positive moderating effect of target firm national security concern on the negative relationship between protectionism and completion, and the positive relationship between protectionism and duration is supported. The fifth hypothesis, on the positive moderating effect of host country GDP growth on the negative relationship between protectionism and completion, and the positive relationship between protectionism and duration, is not supported. This suggests that these relationships between protectionism and cross-border acquisition completion likelihood and duration are not affected by the GDP growth of the host country, in the year the focal deal is announced.

\subsubsection{The Effect of Protectionism on Cross-border Acquisition Completion and Duration}

The results support the hypothesis that the degree of protectionism in the host country is negatively related to the likelihood of completion and positively related to the duration. These results appear to be line with the contention that cross-border acquisitions possess "the permanence, effects on competition or political salience to come under governmental scrutiny" (Conybeare \& Kim, 2010, p. 1177). The cross-border acquisition literature has 
explored institution-based explanations for the beginning and the conclusion of the crossborder acquisition process. However, there is little empirical research which directly links host country protectionism to cross-border acquisitions, let alone specifically to the intermediary stage (middle) of the acquisition process.

Institutional theorists have long argued that external institutions significantly influence an organisation's decision making. However, extant literature has focused on demonstrating the relevance of institution's through simple reference to their existence. By honing in on political and regulatory institutions, I shift focus from static institutional differences to active institutional behaviour. I argue that announced cross-border acquisitions are exposed to protectionism, a macro, national-level component of the institutional environment.

Previous literature suggests, that if severe enough, host institutions' participation, can push uncertainty in the investment environment beyond a manageable threshold of risk (Wan \& Wong, 2009; Reddy et al., 2016; White, 2005). This can contribute to acquisition abandonment or longer durations because of the acquirer's perception that they cannot feasibly carry on with the acquisition in the face of such adversity (Wan \& Wong, 2009; Reddy et al., 2016). By engaging the legitimacy perspective rooted in the institution-based view, I identify legitimacy concerns as a mechanism that links protectionism to crossborder acquisition completion and duration. High legitimacy concerns may prompt excess participation of host country's regulatory institutions in the acquisition process. I find that high legitimacy concerns enable protectionism to reduce the likelihood of completion or increase the time taken to finalise announced cross-border acquisitions, by inducing regulatory scrutiny which may culminate in some measure of government intervention.

\subsubsection{The Moderating Effect of Target Firm Characteristics}

Most researchers contributing to the work on firm-level factors in cross-border acquisitions focus on acquirer characteristics (e.g., Lim \& Lee, 2016; Chari \& Chang, 2009), seldom considering target characteristics. The strong emphasis on the acquirer's attributes is warranted in that it has resulted in robust empirical evidence supporting their significance. Findings indicate that the size and performance of acquirers, in particular, affect crossborder acquisition completion and duration. Both characteristics act as proxies for acquirers' ability to derive successful outcomes from their actions (such as the timely 
completion of a publicly announced acquisition). Size is indicative of the resource base available to firms to pursue success and performance is indicative of skill. Little effort has been made to explore target firm characteristics. An organisation's actions will be pragmatically illegitimate if they are seen as detracting value from the environment in which they take place. Taking a legitimacy perspective, the target firm's size and performance, represent what the host economy stands to lose should the acquisition be completed.

\subsubsection{The Moderating Effect of Target Firm Size}

The hypothesised moderating effect of target firm size on the negative relationship between protectionism and cross-border acquisition completion likelihood was supported in this study. So, too, was the hypothesised moderating effect of target firm size on the positive relationship between protectionism and cross-border acquisition duration. Previous research has found that large and visible cross-border acquisitions are the most likely to be exposed to protectionism, and hence, government interference (Sauvant, 2009; Bertrand et al., 2016). De Beule and Duanmu (2012) suggest that acquirers may "get away with buying smaller...without getting flagged" (p. 267). Cross-border acquisitions concerning large target firms are unlikely to be determined by a market process (Zhang et al., 2011). A market process is based on the will of buyers and sellers and tends not to be embroiled in the politics of government and public opinion (Zhang et al., 2011). Thus, an acquisition of a large target firm is likely to encounter more barriers to completion because it is vulnerable to a wider set of stakeholders (Zhang et al., 2011).

\subsubsection{The Moderating Effect of Target Firm Performance}

The hypothesised moderating effect of target firm performance on the negative relationship between protectionism and cross-border acquisition completion likelihood was supported in this study, as was the hypothesised moderating effect of target firm performance on the positive relationship between protectionism and cross-border acquisition duration. Target performance has been identified as an influential factor in cross-border acquisitions (e.g., De Beule \& Duanmu, 2012) however, its relevance is still tied to the acquirer's perspective. It is a fair assumption that a target firm's performance may contribute to the attractiveness of a deal for the acquirer. I find, by applying a legitimacy perspective, it may also indicate, 
the measure of value the economy stands to lose should the acquisition be completed. Thus, high performing target firms will pique higher legitimacy concerns which fuel protectionism.

\subsubsection{The Moderating Effect of Target Firm National Security Concern}

The hypothesised moderating effect of target firm national security concern on the negative relationship between protectionism and cross-border acquisition completion likelihood was

supported in this study. As was the hypothesised moderating effect of target firm national security concern on the positive relationship between protectionism and cross-border acquisition duration. These findings indicate that if a target firm belongs to an industry sensitive to national security concerns, the announced acquisition is less likely to be completed and, among those completed acquisitions, the duration of the deal will be longer than for a firm without security concerns.

These findings are consistent with past research (e.g., Zhang et al., 2011; Zhang \& He, 2014). Studies have found that national security concerns arise where the acquirer is stateowned and thus, has an implied close affiliation with a domestic government or where acquirers target a "sensitive" or essential infrastructure industry. This is in alignment with the research on acquisitions in specific industries. I find that legitimacy concerns are heightened if acquisitions are thought to create dependencies on foreign-controlled suppliers for crucial goods and services (Moran, 2013, Bertrand et al., 2016). Heightened legitimacy concerns then lead to demonstrations of protectionism against announced crossborder acquisitions. Prior research has found that an acquirer's state ownership "negatively affects a firm's image building process" which ultimately, impacts the success of the actions they take (Cui \& Jiang, 2012, p. 267). National scrutiny concerns irrespective of the source are grounded in host country government's fears of "losing its ability to influence the activities" (Kim, 2007) e.g., preventing the transfer of acquired technologies or sensitive information. Host country institutions are more likely to brand these deals as illegitimate because of the associated political and strategic risks these acquisitions pose (Li et al., 2017).

\subsubsection{The Moderating Effect of Host Country GDP Growth}


The results of this study do not support the hypothesis predicting a moderating effect of the host country's GDP growth. Both the negative relationship between protectionism and cross-border acquisition completion likelihood and the positive relationship between protectionism and cross-border acquisition duration are not affected by the host country's GDP growth. A potential explanation for this result may be that the effect of the host country's GDP growth is confounded by factors not controlled for within this study.

Existing literature has indicated that there is a linkage between GDP growth rate and the extent to which a host government can refrain from engaging in protectionist behaviour for the sake of its economy (Zhou, Lan \& Tang, 2016; Erel et al., 2012). However, empirical studies testing this have produced mixed results.

According to Erel et al. (2012) acquisitions in countries with low GDP growth tend to be easier to complete. Foreign investment may be viewed as a way to rectify negative economic conditions and thus the completion likelihood of acquisitions in this context is greater. However, it is worth noting, that compared to greenfield investments, acquisitions are seen as less likely "to generate additional growth and employment" (Conybeare \& Kim, 2010, p. 1179). Therefore, the perception that foreign acquisitions may provide the answer to economic downturns may be erroneous. The findings arising from Rowoldt and Starke (2016) express the opposite of Erel et al.'s 2012 findings. They suggest that “target nations' governments in prospering economies may want to prevent the allocation of the benefits of the domestic upturn" for vote-seeking reasons (Rowoldt \& Starke, 2016, p. 12). Thus, higher host country GDP growth may in some instances incite protectionism in line with populist sentiment. It is unclear whether host country GDP growth plays a key role in the intermediary stage of cross-border acquisitions.

A considerable number of studies acknowledge that countries with high GDP growth attract more cross-border acquisitions (e.g., Arslan, Tarba \& Larimo, 2015; Xia et al., 2008). This study shows that protectionism in a host country worsens an acquirer's chances of reaching completion, irrespective of the host country's GDP growth in the year of the focal deal. This suggests, that whilst the GDP growth may influence the activities preceding deal announcement such as the selection of a particular target firm based on its location in an 
attractive investment environment, once that acquisition has been announced, the completion and duration of the deal are more likely to be at the mercy other forces. For example, protectionism that causes legitimacy concerns for sociological or political reasons, more so than economic ones (Dinc \& Erel, 2013). Further work is called for, to ascertain whether and how, host country GDP growth has a tempering or exacerbating effect on protectionism in cross-border acquisitions.

\subsection{Implications}

\subsubsection{Theoretical Contribution and Implications}

My study makes three contributions to the acquisition literature from an institution-based perspective. First, it validates the importance the target firm's size, performance and nature of industry in the relationship between host country protectionism and multinational corporations' cross-border acquisitions. The identification of boundary conditions of the phenomenon, particularly at the target firm level, will aid future researchers in extending the state of literature. Though recent research has generally emphasised the protectionist behaviour of host governments towards foreign firms, much less is known about the conditions under which the adverse effects on multinational corporations are more pronounced or are minimised. Utilising a legitimacy perspective, my research adds to existing literature by indicating that the characteristics of the target firm moderate the effect of protectionism on cross-border acquisition and duration. Specifically, cross-border acquisitions of large, high performing target firms within national security industries are the most susceptible to the influence of protectionism because they induce legitimacy concerns in host country institutions. The more intense these concerns, the more intense the protectionism experienced.

Second, by examining protectionism, a macro, national-level component of the institutional environment, and its effect on cross-border acquisitions, this study contributes to the acquisition literature by introducing the under-researched area of protectionism. My findings have furthered our understanding of how the institutional environment, particularly, political institutions, may influence the outcome of cross-border acquisition attempts. This study responds to the increased interest in institution-based explanations of announced cross-border acquisition completions and durations. A number of studies have 
begun to turn to institutional reasons to explain why announced cross-border acquisitions fail (e.g., institutional differences). For the most part, these enquiries have addressed institutions as static structures, as compliance officers and audiences of investment (Bitektine, 2011). Their mere existence has been extensively scrutinised as an impediment to cross-border acquisitions (e.g., Dikova et al., 2010, Zhou, Xie \& Wang, 2016). In addition to providing further theoretical and empirical evidence for their relevance, my focus on protectionism can enrich the literature by addressing the limited attention given to the behaviour of institutions. The passive role allocated to host country institutions in the literature not only limits current research, but also underestimates their importance (Bitektine, 2011). The present study underscores institutions as playing a role in the outcome of acquisition attempts in which they take interest.

The analysis presented in this study is not restricted to questioning whether regulatory scrutiny affects cross-border acquisitions as has been the case with prior work, rather it extends into the motivation driving this scrutiny and into investigating if actual acts of protectionism in a host country are sound predictors of the outcomes of announced crossborder acquisitions. In doing so, it emphasises legitimacy concerns as a key mechanism that links protectionism to cross-border acquisition completion and duration.

\subsubsection{Managerial Implications}

It is commonly thought that sound governments, especially democracies, encourage crossborder acquisitions because they offer stable legal environments (Conybeare \& Kim, 2010, p. 1182). Whilst it may be true that democratic host governments create attractive FDI locations, several researchers examining the intermediary phase of the acquisition process allude to empirical evidence which suggests that a number of firms abandon their acquisition attempts at some point prior to completion (e.g., Dikova et al., 2010; Zhang et al., 2011; Shimizu et al., 2004). Joining this group, I propose that one of the factors that may compromise a firm's efforts to complete an announced acquisition is the protectionist behaviour of the host country government. Such a focus is both timely and relevant considering the current tone of foreign affairs, the numerous anecdotal accounts of undue host-government interference and the confusing incongruence between the liberal policies of FDI locations and their protectionist reactions towards cross-border acquisitions. The 
results of this study suggest that managers should factor the protectionist inclinations of their location choice into their decision to lodge a bid.

A more comprehensive understanding of deal breakers is crucial because acquirers incur considerable upfront costs in making the initial bid. Acquirers may also suffer from credibility damages arising to firms breaching publicised acquisition deals (Dikova et al., 2010). The abandonment of an acquisition prior to its announcement may result in wasted time and money. By contrast, the abandonment of an acquisition after its public announcement but, prior to its completion, may result in additional and more severe losses such as serious damage to the acquirer's reputation and credibility, the exposure of their corporate strategy or a termination fee (Officer, 2003; Lim \& Lee, 2016). This study provides insight that will mean acquirers can craft strategies which address forecasted difficulties with protectionism. For example, if a prospective acquirer is aware of the potential for host country protectionism and wishes to proceed, an appropriate strategy may be to open with an attractive offer. A high bid is more likely to appeal to target firm stakeholders and domestic governments than a conservative bid. This may counterbalance the effect of high legitimacy concerns and thus mitigate the harmful effect of protectionism (Bertrand et al., 2016). Furthermore, cross-border acquisitions are a process. Assuming that the desired result of this process is not only that a deal is completed but, that the process gives rise to a profitable new venture, "directly addressing problems that may cause deal abandonment or the protraction of a deal completion ex ante may prevent incurring high ex post costs" (Dikova et al., 2010, p. 225). Furthermore, the avoidance of a drawn-out acquisition deal may positively impact the subsequent integration performance (Dikova et al., 2010).

\subsection{Limitations and Future Research}

The limitations of this study are clear. Firstly, it uses a sample of only publicly listed target and acquirer firms. Public firms tend to be larger and better performers than other firms. These characteristics increase the negative effect of host government protectionism on cross-border acquisitions firstly because, large or high performing target firms tend to exacerbate the effect of protectionism on the completion and duration of cross-border acquisitions. Secondly, previous research has linked the visibility of the deal, in terms of 
the size of the parties and transaction, to the degree to which it is subject to host country protectionism (Bertrand et al., 2016). A large deal is more likely to attract the attention of the host country government (Bertrand et al., 2016). Third, publicly listed firms, more so than private entities, must comply with national and international regulations and experience intense monitoring (Weston, Mitchell, \& Mulherin, 2004; Li et al., 2017). Such intensive compliance requirements may cause delays that non-public firms can normally avoid. For these reasons, this study may overemphasise the effect of host country protectionism on announced cross-border acquisitions. Future work might investigate whether the results of this study hold for small or privately-owned firms. It is entirely possible that acquisitions of some small target firms (e.g., high-profile start-ups) or private firms of substantial size, are equally as visible as those of large targets (Bertrand et al., 2016).

Second, the results of this study must be taken with a level of caution given that the theory was tested only in the context of developed market economies and "legitimacy concerns vary across institutional environments" (Li et al., 2017, p. 1931). Future research is encouraged to examine if this theoretical framework can be generalised to explain crossborder acquisition completions and durations in different contexts. It would be particularly advantageous for researchers to conduct comparative studies between developed and developing economies. A sample of host countries with more varied economic conditions may reconcile the inconclusive results as to the effect of the host country's GDP growth and tease out further insights.

Third, this study may not provide an adequate representation of the magnitude of protectionism's effect on cross-border acquisitions. A sample of attempted bids was required to analyse whether protectionism affects the completion and duration of acquisitions. Bids are unlikely to take place unless the acquirer is sufficiently confident that the acquisition will be completed. This approach cannot capture the effect of protectionism on bids that were never made because acquirers were weary of a host country's protectionist tendencies. Dinc and Erel (2013) found evidence of such a deterrent effect and the same conclusion was reached in Callaghan (2015), highlighting that "the mere threat of intervention can deter potential bidders" (p. 397). Bids that are curtailed by protectionism 
before officially occurring are impossible to count. Future research might control for this by taking a two-stage approach. By widening the sample to-include potential acquirers rather than just acquirers who have placed bids, the propensity for protectionism to influence whether or not a bid is made i.e. the likelihood of announcement, can be factored into the analysis alongside cross-border acquisition completion likelihood and duration. Future research might examine if host-country protectionism affects acquirers' location choice or entry-mode decisions. Work to this effect, will provide a more accurate picture of the severity of protectionism for foreign firms. Protectionism may very well deter cross-border acquisitions however, it is likely to prompt firms to modify their strategies, not to lead to a halt in international economic activity all together.

Although the conclusion that emerges from this study is comparable to those of previous works (e.g., Dinc \& Erel, 2013, Aktas et al., 2007), this study has only addressed the question of trade protectionism. WTO-recorded acts of trade protectionism are operationalised in this study to serve as a proxy for protectionism because of the WTO's transparent reporting system and the resulting ease of measurement. However, it is not clear whether acts of trade protectionism represent the general degree to which a country is protectionist and thus, it is not clear whether excessive recourse to trade protectionism provides a fair indication of the extent to which a host country engages in protectionism towards other economic activities. Future studies could look at multiple dimensions of the protectionism, as well other economic activities undertaken by foreign firms.

\subsection{Conclusion}

This study investigates the effect of protectionism on the completion likelihood and duration of announced cross-border acquisitions. Additionally, it investigates the significance of four boundary conditions that may attenuate, or exacerbate, the degree of protectionism experienced by prospective foreign acquirers. These include; target firm size, target firm performance, and target firm national security concerns at the firm-level and the economic condition of the host country at the national-level. Notwithstanding its limitations, the empirical evidence resulting from the study suggests that the higher the incidence of protectionist activity in a host country, the lower the likelihood of completion, and the longer the duration of announced cross-border acquisitions. 
Furthermore, by considering the target firm's characteristics as boundary conditions, that may augment the degree to which protectionist institutions affect announced cross-border acquisitions, the study contributes to knowledge in this area by uncovering in which situations host protectionism is a relevant consideration during target firm selection activities. In doing so, it contributes to the growing stream of literature that applies an institution-based view perspective to the intermediary cross-border acquisition phase. Secondly, by shedding light on the relevance of target firm characteristics, this study addresses the current bias towards examining acquirer attributes alone in cross-border acquisition research. Despite its preliminary character, by providing empirical evidence of a relationship between host country protectionism and cross border acquisition attempts, this research highlights legitimacy concerns as a mechanism through which protectionism can account for the government intervention that contributes to prolonged cross-border acquisition durations and abandonments. 


\section{REFERENCES}

Aktas, N., Bodt, E., \& Roll, R. (2007). Is European M\&A regulation protectionist?*. Economic Journal, 117(522), 1096-1121.

Ang, S. H. (2014). Research design for business and management. London: SAGE Publications Ltd.

Ang, S., Benischke, M., \& Doh, J. (2015). The interactions of institutions on foreign market entry mode. Strategic Management Journal, 36(10), 1536-1553.

Angwin, D. (2001). Mergers and acquisitions across European borders: National perspectives on pre-acquisition due diligence and the use of professional advisors. Journal of World Business, 36(1), 32-57.

Arslan, A., Tarba, S. Y., \& Larimo, J. (2015). FDI entry strategies and the impacts of economic freedom distance: Evidence from Nordic FDIs in transitional periphery of CIS and SEE. International Business Review, 24(6), 997-1008.

Baldwin, R., \& Evenett, S. (Eds.). (2009). The collapse of global trade, murky protectionism, and the crisis: Recommendations for the G20. London: Centre for Economic Policy Research.

Bertrand, O., Betschinger, M., \& Settles, A. (2016). The relevance of political affinity for the initial acquisition premium in cross-border acquisitions. Strategic Management Journal, 37(10), 2071-2091.

Bitektine, A. (2011). Toward a theory of social judgments of organization: the case of legitimacy, reputation, and status. Academy of Management Review 36(1), 151-179.

Bittlingmayer, G., \& Hazlett, T. W. (2000). DOS Kapital: Has antitrust action against Microsoft created value in the computer industry? Journal of Financial Economics, 55(3), 329-359.

Boddewyn, J. J., \& Brewer, T. L. (1994). International-business political behavior: New theoretical directions. Academy of Management Review 19(1), 119-143.

Boone, A. L., \& Mulherin, J. H. (2007). How are firms sold? Journal of Finance, 62(2), $847-875$.

Chari, M. D. R., \& Chang, K. (2009). Determinants of the share of equity sought in crossborder acquisitions. Journal of International Business Studies, 40(8), 1277-1297. 
Chen, Z., Han, B., \& Zeng, Y. (2017). Financial hedging and firm performance: Evidence from cross-border mergers and acquisitions. European Financial Management, $23(3), 415-458$.

Chung, C., Xiao, C., Lee, S., \& Kang, S. (2016). The interplay of top-down institutional pressures and bottom-up responses of transition economy firms on FDI entry mode choices. Management International Review, 56(5), 699-732.

Context. (n.d.). In English Oxford living dictionaries. Retrieved February 3, 2018, https://en.oxforddictionaries.com/definition/context.

Conybeare, J., \& Kim, D. H. (2010). Barbarians at the gates: State control of global mergers and acquisitions. The World Economy, 33(9), 1175-1199.

Coxe, S., West, S., \& Aiken, L. (2009). The analysis of count data: A gentle introduction to Poisson regression and its alternatives. Journal of Personality Assessment, 91(2), $121-136$.

Cui, L., \& Jiang, F. (2012). State ownership effect on firms' FDI ownership decisions under institutional pressure: A study of Chinese outward-investing firms. Journal of International Business Studies 43(3), 264-284.

De Beule, F., \& Duanmu, J. L. (2012). Locational determinants of internationalization: A firm-level analysis of Chinese and Indian acquisitions. European Management Journal, 30(3), 264-277.

Dikova, D., Sahib, P. R, \& van Witteloostuijn, A. V. (2010). Cross-border acquisition abandonment and completion: The effect of institutional differences and organizational learning in the international business service industry, 1981-2001. Journal of International Business Studies 41(2), 223-245.

Dinc, S., \& Erel, I. (2013). Economic nationalism in mergers and acquisitions. Journal of Finance, 68(6), 2471-2514.

Enderwick, P. (2011). Understanding the rise of global protectionism. Thunderbird International Business Review, 53(3), 325-336.

Erel, I., Liao, R. C., \& Weisbach, M. (2012). Determinants of cross-border mergers and acquisitions. Journal of Finance, 67(3), 1045-1082.

Faelten, A., Gietzmann, M., \& Vitkova, V. (2015). Learning from your investors: Can the geographical composition of institutional investors affect the chance of success in international M\&A deals? Journal of Management \& Governance, 19(1), 47-69. 
Fortune. (2017). Fortune 500. Retrieved from http://www.fortune.com

Gartzke, E., \& Gleditsch, K. S. (2006). Identity and conflict: Ties that bind and differences that divide. European Journal of International Relations 12(1), 53-87.

Globerman, S., \& Shapiro, D. (2009). Economic and strategic considerations surrounding Chinese FDI in the United States. Asia Pacific Journal of Management 26(1), 163183.

Hansen, R. G. (2001). Auctions of companies. Economic Inquiry 39(1), 30-43.

Heinemann, A. (2012). Government control of cross-border M\&A: Legitimate regulation or protectionism? Journal of International Economic Law, 15(3), 843-870.

Hemphill, T. A. (2010). The 'new protectionism': Industrial policy barriers to cross-border mergers and acquisitions. Competition \& Change, 14(2), 124-148.

Henisz, W. (2000). The institutional environment for economic growth. Economics \& Politics, 12(1), 1-31.

Hofstede, G. (1980). Culture's consequences: International differences in work-related values. Beverly Hills, CA: Sage.

Holburn, G. L. F, \& Zelner, B. A. (2010). Political capabilities, policy risk and international investment strategy: evidence from the global electric power industry. Strategic Management Journal 31(12), 1290-1315.

Hotchkiss, E. S., Qian, J., \& Song, W. (2005). Holdups, renegotiation and deal protection in mergers (Working Paper No. 4705365). Retrieved from Social Science Research Network http://www.ssrn.com

Hughes, O. E. \& O’Neill, D. (2008). Business, government and globalization. New York, NY: Palgrave Macmillan.

Jemison, D. B., \& Sitkin, S. B. (1986). Acquisitions: The process can be a problem. Harvard Business Review, 64(2), 107-116.

Keats, B. W., \& Hitt, M. A. (1988). A causal model of linkages among environmental dimensions, macro organizational characteristics, and performance. Academy of Management Journal, 31(3), 570-598.

Kim, J. (2007). Fears of foreign ownership: The old face of economic nationalism. Review of International Affairs, 27(2), 167-177. 
Kleinbaum, D. G., \& Klein, M. (2009). Logistic regression: A self-learning text (3rd ed.). New York, NY: Springer.

Kogut, B., \& Singh, H. (1988). The effect of national culture on the choice of entry mode. Journal of International Business Studies 19(3), 411-432.

Li, J., Xia, J., \& Lin, Z. (2017). Cross-border acquisitions by state-owned firms: How do legitimacy concerns affect the completion and duration of their acquisitions? Strategic Management Journal, 38(9), 1915-1934.

Lim, M., \& Lee, J. (2016). The effects of industry relatedness and takeover motives on cross-border acquisition completion. Journal of Business Research, 69(11), 47874792.

Lim, M., \& Lee, J. (2017). National economic disparity and cross-border acquisition resolution. International Business Review, 26(2), 354-364.

Luo, Y. (2005). Do insiders learn from outsiders? Evidence from mergers and acquisitions. Journal of Finance 60(4), 1951-1982.

Meyer, K. E., Ding, Y., Li, J., \& Zhang, H. (2014). Overcoming distrust: How state-owned enterprises adapt their foreign entries to institutional pressures abroad. Journal of International Business Studies 45(8), 1005-1028.

Meyer, K. E., Estrin, S., Bhaumik, S. K., \& Peng, M. W. (2009). Institutions, resources, and entry strategies in emerging economies. Strategic Management Journal, 30(1), $61-80$.

Moran, T. (2013). Foreign acquisitions and national security: What are genuine threats? What are implausible worries? In Z. Drabek \& P. C. Mavroidis (Eds.), Regulation of foreign investment: Challenges to international harmonization (pp. 371-393).

Retrieved from http://www.books.google.com

Morosini, P., Shane, S., \& Singh, H. (1998). National cultural distance and cross-border acquisition performance. Journal of International Business Studies, 29(1), 137-158.

Moschieri, C., Ragozzino, R., \& Campa, J. M. (2014). Does regional integration change the effects of country-level institutional barriers on M\&A? The case of the European Union. Management International Review, 54(6), 853-877.

Muehlfeld, K., Sahib, P. R., \& Witteloostuijn, A. V. (2007). Completion or abandonment of mergers and acquisitions: Evidence from the newspaper industry, 1981-2000. Journal of Media Economics 20(2), 107-137. 
North, D. (1990). Institutions, institutional change and economic performance. Cambridge: Cambridge University Press.

North, D. (1991). Institutions. The Journal of Economic Perspectives, 5(1), 97-112.

Officer, M. S. (2003). Termination fees in mergers and acquisitions. Journal of Financial Economics, 69(3), 431-467.

Oldford, E., \& Otchere, I. (2016). Are cross-border acquisitions enemy of labor? An examination of employment and productivity effects. Pacific-Basin Finance Journal, 40, 438-455.

Popli, M., Akbar, M., Kumar, V., \& Gaur, A. (2016). Reconceptualizing cultural distance: The role of cultural experience reserve in cross-border acquisitions. Journal of World Business, 51(3), 404-412.

Popli, M., \& Kumar, V. (2016). Jumping from Springboard? The role of marginal cultural distance in cross-border M\&A deal completion. Thunderbird International Business Review, 58(6), 527-536.

Rabinovich, E., \& Cheon, S. (2011). Expanding horizons and deepening understanding via the use of secondary data sources. Journal of Business Logistics, 32(4), 303-316.

Reddy, K. S., Xie, E., \& Huang, Y. (2016). The causes and consequences of delayed/abandoned cross-border merger \& acquisition transactions. Journal of Organizational Change Management, 29(6), 917-962.

Rowoldt, M., \& Starke, D. (2016). The role of governments in hostile takeovers - evidence from regulation, anti-takeover provisions and government interventions. International Review of Law and Economics, 47, 1-15.

Sauvant, K. P. (2009). FDI protectionism is on the rise (Policy Research Working Paper No. 5052). Retrieved from http://www.econ.worldbank.org

Sauvant, K. P. (2010). Is the United States ready for foreign direct investment from emerging markets? The case of China. In K. P. Sauvant, G. McAllister, \& W. A. Maschek (Eds.), Foreign direct investments from emerging markets: The challenges ahead (pp. 359-380). New York, NY: Palgrave Macmillan.

Shultz, K. S., Hoffman, C. C., \& Reiter-Palmon, R. (2005). Using archival data for I-O research: Advantages, pitfalls, sources, and examples. Psychology Faculty Publications, 42(3), 31-37. 
Scott, W. R. (1995). Institutions and Organizations. Thousand Oaks, CA: SAGE Publications Inc.

Shimizu, K., Hitt. M., Vaidyanath, D., \& Pisano, V. (2004). Theoretical foundations of cross-border mergers and acquisitions: A review of current research and recommendations for the future. Journal of International Management, 10(3), 307353.

Shin, A. (2009, March 27). WTO says protectionism could prolong recession. Washington Post. Retrieved from http://www.washingtonpost.com

Slangen, A. H. L., \& van Tulder, R. J. M. (2009). Cultural distance, political risk, or governance quality? Towards a more accurate conceptualization and measurement of external uncertainty in foreign mode research. International Business Review, $18(3), 276-291$.

Spencer, B. (1995). Correlations, sample size, and practical significance: A comparison of selected psychological and medical investigations. Journal of Psychology, 129(4), 469-75.

Stevens, C., Xie, E., \& Peng, M. (2016). Toward a legitimacy-based view of political risk: The case of Google and Yahoo in China. Strategic Management Journal, 37(5), 945-963.

Suchman, M. C. (1995). Managing legitimacy: Strategic and institutional approaches. Academy of Management Review 20(3), 571-610.

Tingley, D., Xu, C., Chilton, A., \& Milner, H. V. (2015). The political economy of inward FDI: Opposition to Chinese mergers and acquisitions. Chinese Journal of International Politics, 8(1), 27-57.

Toth, J. M. (2008). Cross-border M\&A deals: National security and interest reviews raise flags. Inside Counsel, 18, 20-21.

UNCTAD. (1996). World investment report 1996: Investment, trade and international policy arrangements. Retrieved from http://www.unctad.org

UNCTAD. (2016). World investment report 2016: Key messages and overview. Retrieved from http://www.unctad.org

UNCTAD. (2017). World investment report 2017: Investment and the digital economy. Retrieved from http://www.unctad.org 
Vermeulen, F., \& Barkema, H. G. (2001). Learning through acquisitions. Academy of Management Journal, 44(3), 457-476.

Very, P., Lubatkin, M., Calori, R., \& Veiga, J. (1997). Relative standing and the performance of recent European mergers. Strategic Management Journal, 18(8), 593-614.

Wan, K. M., \& Wong, K. F. (2009). Economic impact of political barriers to cross-border acquisitions: An empirical study of CNOOC's unsuccessful takeover of Unocal. Journal of Corporate Finance 15(4), 447-468.

Weston, J. F., Mitchell, M. L., \& Mulherin, J. H. (2004). Takeovers, restructuring and corporate governance (4th ed.). Englewood Cliffs, NJ: Prentice-Hall.

White, B. (2005, August 3). Chinese drop bid to buy U.S. oil firm. Washington Post. Retrieved from http://www.washingtonpost.com

Wilson, B. D. (1980). The propensity of multinational companies to expand through acquisitions. Journal of International Business Studies, 11(1), 59-64.

WTO. (2017a). Report on G20 trade measures. Retrieved from http://www.wto.org

WTO. (2017b). World Trade Organisation. Retrieved from http://www.wto.org

Xia, J., Tan, J., \& Tan, D. (2008). Mimetic entry and bandwagon effect: The rise and decline of international equity joint venture in China. Strategic Management Journal, 29(2), 195-217.

Xie, E., Reddy, K. S., \& Liang, J. (2017). Country-specific determinants of cross-border mergers and acquisitions: A comprehensive review and future research directions. Journal of World Business, 52(2), 127-183.

Zaheer, S., Schomaker, M. S., \& Nachum, L. (2012). Distance without direction: Restoring credibility to a much-loved construct. Journal of International Business Studies, 43(1), 18-27.

Zhang, J., \& He, X. (2014). Economic nationalism and foreign acquisition completion: The case of China. International Business Review 23(1), 212-227.

Zhang, J., He, X., \& van Gorp, D. M. (2017). Economic freedom and cross-border acquisitions from emerging markets into developed economies. Thunderbird International Business Review, 59(3), 313-331. 
Zhang, J., Zhou, C., \& Ebbers, H. (2011). Completion of Chinese overseas acquisitions: Institutional perspectives and evidence. International Business Review 20(2), 226238.

Zhou, J., Lan, W., \& Tang, Y. (2016). The value of institutional shareholders. Management Decision, 54(1), 44-65.

Zhou, C., Xie, J., \& Wang, Q. (2016). Failure to complete cross-border M\&As: "To" vs. "From" emerging markets. Journal of International Business Studies, 47(9), 10771105. 